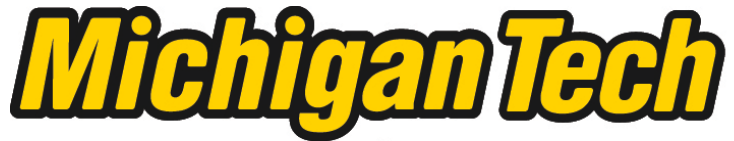 \\ Michigan Technological University Create the Future Digital Commons @ Michigan Tech
}

Dissertations, Master's Theses and Master's Reports - Open

Dissertations, Master's Theses and Master's

Reports

2009

\section{Federal and state policy influence on woody biomass utilization}

Susan Balint

Michigan Technological University

Follow this and additional works at: https://digitalcommons.mtu.edu/etds

Part of the Environmental Policy Commons

Copyright 2009 Susan Balint

\section{Recommended Citation}

Balint, Susan, "Federal and state policy influence on woody biomass utilization", Master's Thesis, Michigan Technological University, 2009.

https://doi.org/10.37099/mtu.dc.etds/293

Follow this and additional works at: https://digitalcommons.mtu.edu/etds

Part of the Environmental Policy Commons 
Federal and State Policy Influence on Woody Biomass Utilization

\author{
By \\ Susan Balint \\ A THESIS \\ Submitted in partial fulfillment of the requirements \\ for the degree of \\ MASTER OF SCIENCE IN ENVIRONMENTAL POLICY \\ MICHIGAN TECHNOLOGICAL UNIVERSITY \\ 2009
}

Copyright (C) Susan Balint 2009 
This thesis, "Federal and State Policy Influence on Woody Biomass Utilization,” is hereby approved in partial fulfillment of the requirements of the Degree of MASTER OF SCIENCE IN ENVIRONMENTAL POLICY

DEPARTMENT or PROGRAM

Social Sciences - Environmental Policy

Signatures:

Thesis Advisor

Typewritten Name: Dr. Kathleen E. Halvorsen

Department Chair

Typewritten name: Dr. Patrick Martin

Date 


\section{Acknowledgements}

I would like to express my gratitude to Dr. Andrew Storer, Dr. Hugh Gorman, and especially to Dr. Kathleen Halvorsen. Thank you all for your patience and inspiration during this process. I would not have been able to complete this thesis without you. Furthermore, I am grateful to my family, friends, and colleagues for their unwavering support in my endeavors. Thank you. 


\section{Table of Contents}

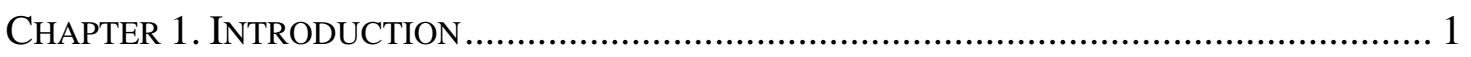

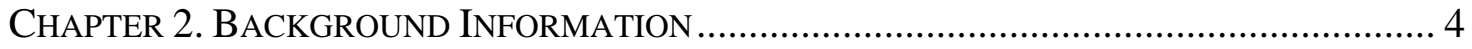

CHAPTER 3. SCHOLARLY LITERATURE REVIEW ....................................................... 15

Woody Biomass Utilization as a Wildfire Mitigation Tool...................................... 15

Bioenergy and Small-Diameter Utilization of Woody Biomass............................... 20

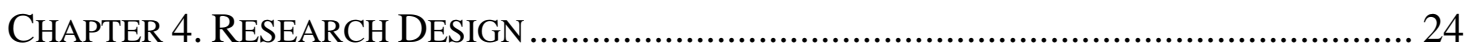

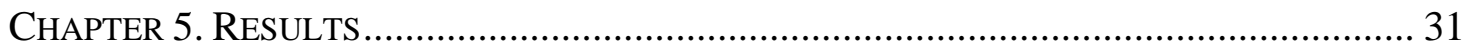

Federal Policies Related to Woody Biomass Utilization.......................................... 32

Federal Agencies Involved with Woody Biomass Utilization .................................. 41

State Policies and Woody Biomass Utilization ..................................................... 45

Potential Future Policy Considerations ............................................................. 48

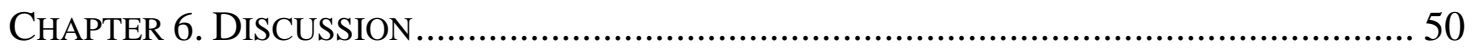

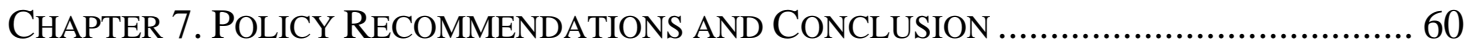

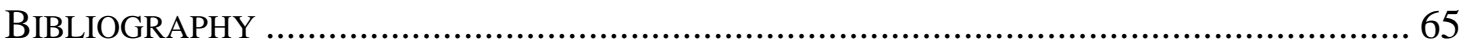

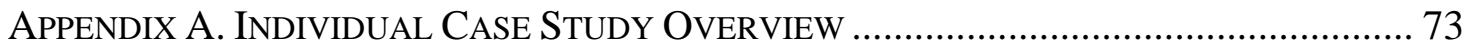

APPENDIX B. CASE STUDY INTERVIEW QUESTIONS .............................................. 82 


\section{Abstract}

A considerable portion of public lands in the United States is at risk of uncharacteristically severe wildfires due to a history of fire suppression. Wildfires already have detrimental impacts on the landscape and on communities in the wildlandurban interface (WUI) due to unnatural and overstocked forests. Strategies to mitigate wildfire risk include mechanical thinning and prescribed burning in areas with high wildfire risk. The material removed is often of little or no economic value. Woody biomass utilization (WBU) could offset the costs of hazardous fuel treatments if removed material could be used for wood products, heat, or electricity production. However, barriers due to transportation costs, removal costs, and physical constraints (such as steep slopes) hinder woody biomass utilization.

Various federal and state policies attempt to overcome these barriers. WBU has the potential to aid in wildfire mitigation and meet growing state mandates for renewable energy. This research utilizes interview data from individuals involved with on-theground woody biomass removal and utilization to determine how federal and state policies influence woody biomass utilization. Results suggest that there is not one overarching policy that hinders or promotes woody biomass utilization, but rather woody biomass utilization is hindered by organizational constraints related to time, cost, and quality of land management agencies’ actions. However, the use of stewardship contracting (a hybrid timber sale and service contract) shows promise for increased WBU, especially in states with favorable tax policies and renewable energy mandates. Policy recommendations to promote WBU include renewal of stewardship contracting 
legislations and a re-evaluation of land cover types suited for WBU. Potential future policies to consider include the indirect role of carbon dioxide emission reduction activities to promote wood energy and future impacts of air quality regulations. 


\section{Chapter 1. Introduction}

In recent years, a confluence of events centered on the need for renewable sources of energy and effective ways to prevent catastrophic wildfires has evolved into efforts to profitably and effectively utilize woody biomass in the United States. Woody biomass is comprised of forest residues and sawmill residues, which is the focus of this study. Biomass, in general, is defined as "all plant and plant-derived materials including animal manure” (Perlack et al., 2005 p. 1). Woody biomass is considered the "nonmerchantable” wood in a forested area. This includes the top and limbs of trees, small diameter trees, and brush. In other words, woody material that has no value in the timber and pulpwood markets (Evans, 2008).

Woody biomass utilization (WBU) is defined by the United States Forest Service as "the harvest, sale, offer, trade, or utilization of woody biomass to produce bio-energy and the full range of biobased products" (USFS, 2008). "Biobased products" include items such as wood chips, wood pellets, and wood products such as posts and poles. Utilizing woody biomass is important because it can reduce costs associated with fire risk reduction strategies, and assist in achieving rural economic development goals. In addition, WBU aids in meeting renewable energy goals and mitigating climate change through the avoidance of fossil fuel use (Malmsheimer et al., 2008). Three federal departments are involved in promoting woody biomass removal and utilization - the United States Department of Agriculture (USDA), the United States Department of the Interior (US DOI), and the United States Department of Energy (US DOE). They have a Memorandum of Understanding (MOU) designed to “develop and apply consistent and 
complementary policies and procedures” across the three agencies (USDA, DOI, DOE 2003, p. 1). In addition, a number of national level policies, such as the Healthy Forest Restoration Act, and the National Fire Plan are designed to facilitate WBU. Numerous reports and journal articles discuss the "lessons learned” from woody biomass removal and, to a lesser extent, utilization of woody biomass. My research focuses on understanding how WBU participants believe federal, state, and local policies affect their projects.

An estimated 90 to 200 million acres of public land are in need of fuel reduction treatments (Keiter, 2006). Therefore, utilizing wood from hazardous fuel reduction projects can offset costs. Combining the need for hazardous fuel reduction treatments with bioenergy projects presents a potential "win-win” situation for land managers. Furthermore, if grown sustainably, woody biomass is a renewable and carbon-neutral resource. The use of wood as a building material and as a source of energy could increase as the world shifts to a low-carbon economy (Aulisi et al., 2008). While the role of forest and wood products in mitigating climate change is outside the scope of this research, it is an important dimension to consider since this emerging issue could have larger implications in the future (Aulisi et al., 2008).

Through my research, I tried to understand the impacts of federal and state fire policies and renewable energy policies on current WBU activities. I utilized interview data from a larger research project and analyzed interviewee responses that described their perceptions towards federal, state, and local policies.

My research is derived from a larger project funded by the USDA and US DOI 
Joint Fire Sciences Program. The purpose of the larger study was to provide a descriptive narrative of WBU activities at ten case studies. Key people (between seven and twenty individuals) were interviewed for each case study. Case study locations were chosen to include various administrative units and agencies across different regions of the country. The main goal was to capture and report on the full range of biomass utilization activities. The second goal was to identify key trends and patterns across all case studies in regards to WBU barriers and success strategies. The larger project focused on economic, social, and ecological impacts of WBU for local communities and government agencies. My research involved analyzing interviewee responses to a specific interview question about the effects of federal, state, and local policies on woody biomass utilization. My research data are based on 126 interviews with government employees, timber industry workers, and nonprofit organization workers. Results suggest that federal and state policies play an important role in WBU, however, policy effectiveness is greatly influence by agency procedural requirements and organizational constraints.

This research highlights the dual role of both federal and state policies in WBU. In order to understand the impacts of policies in this research Chapter Two will provide background information on the policy context of WBU followed by a scholarly literature review in Chapter Three. Chapter Four presents my research design, followed by results in Chapter Five. Chapter Six includes a discussion of the results and explains how the results contribute to scholarly literature. Chapter Seven concludes my thesis and presents limitations to this research, ideas for future research, and policy recommendations. 


\section{Chapter 2. Background Information}

Recent increases in the price of fossil fuels, such as oil, coupled with the perceived benefits of "home-grown" energy have recharged interest in renewable sources of energy. Solar, wind, hydroelectric, geothermal, and biomass are forms of renewable energy. Biomass, in its broadest sense, is "all plant and plant-derived materials including animal manure” (Perlack et al, 2004 pg 1). Biomass energy is the most prevalent form of renewable energy in the United States supplying over 3\% of the nation's energy (Perlack et al., 2004).

Sources of woody biomass include wood discarded at waste facilities, sawmill residues, logging residues, and material removed from land treated to reduce the risk of wildfire. The need to reduce the risk of catastrophic wildfires creates public interest in woody biomass utilization (Becker et al., 2009). Material removed from overstocked land is often masticated and left behind in piles to decompose (LeVan-Green and Livingston, 2009). An estimated 60 million dry tons of material is available, annually, from hazardous fuel reduction treatments (Perlack et al, 2005). The utilization of this typically non-merchantable material could have a positive ripple effect on local communities through local job creation and increased wildfire protection. For areas traditionally centered on the timber industry, the prospect of local job creation is especially important (Becker et al., 2009).

Woody biomass utilization cannot occur without collecting or removing the material. Transportation costs limit the haul distances of material. Therefore, sites, which use woody biomass for wood products, electricity, or heat production, must be relatively 
close to where the material originates. This realization often devolves into a "chicken vs. egg” dilemma. A perceived lack of reliable supply hinders woody biomass utilization while conversely, a lack of production facilities makes it difficult to use the material. With estimates of between 90 million to 200 million acres of federal land in need of thinning to reduce fire risk (Keiter, 2006), public lands could provide a considerable amount of material. However, multiple values and purposes dictate public land management through public land policies. While many public land policies exist, The National Fire Plan of 2000, The Healthy Forest Restoration Act of 2003, The National Environmental Policy Act of 1969, and stewardship contracting authority are important policies that aid in wild fire risk reduction.

\section{The National Fire Plan of 2000}

The National Fire Plan (NFP) arose out of the need to effectively deal with the increasing frequency of catastrophic forest fires and their related costs. It is actually more than one piece of legislation and contains a series of reports, strategies, and congressional directives meant as a response to the catastrophic fire season of 2000 (GAO, 2001). The NFP acknowledges fire as an important ecosystem-health management tool yet stresses the importance of wildfire suppression (Dale, 2006). One of the plan's objectives is to incorporate fire use as a land management tool. However, concern over smoke, budgetary limits and difficulties in fire plan execution hampers fire use (Stephens and Ruth, 2005). The National Fire Plan applies to all federal land management agencies. The two largest, the United States Forest Service (USFS) and the Bureau of Land Management (BLM), 
have organizational differences which makes coordination and communication difficult (GAO, 2001). For instance, the USFS, BLM, and National Park Service (NPS) have their own computer models to assess their agency's wildfire preparedness needs. Congressional funding is requested based on these individual agency models. This process fosters a lack of coordination (GAO, 2001). One strategy promoted through the NFP involved mechanical thinning of overstocked forests. Due to increased public concerns about wildfire risk to private land, Congress sought to promote fuel reduction projects in the wildland-urban interface (WUI). In 2003, Congress passed the Healthy Forest Restoration Act (Keiter, 2006) thereby declaring to land management agencies the concern that the risk of wildfire be reduced in the WUI.

\section{The Healthy Forest Restoration Act of 2003}

The Healthy Forest Restoration Act (HFRA) of 2003 set out to expedite the administrative and procedural processes involved in federal forest thinning (Stephens and Ruth, 2005). HFRA does this by reducing environmental protection and public participation requirements. For instance, HFRA calls for "prompt” judicial review of cases with a potential to delay thinning activities and use categorical exclusions (discussed in the next section) to bypass NEPA requirements. Furthermore, HFRA directs at least $50 \%$ of federal hazardous fuel reduction appropriated-funds for use in the WUI (Keiter, 2006).

An important provision involves HFRA’s requirement for Community Wildfire Protection Plans (CWPPs) (Stephens and Ruth, 2005). CWPPs integrate the local community into the planning process for hazardous fuel mitigation plans. 
Communities that participate in the creation and implementation of a CWPP are to receive priority in HFRA projects. Focusing public funds on areas that communities identify as important is a way to increase community support for agency management (Evans, 2008).

Another important HFRA element is the stewardship contracting provision to perform hazardous fuel reduction techniques. These federal contracts are used to achieve land management goals and aid in rural economic development. Local companies and contractors are issued contracts with the goal of creating benefits for the local community (forestsandrangelands.gov, 2008).

The NFP and HFRA are fire-mitigation oriented policies that apply to land management agencies. Both encourage the removal of material from overstocked forests. The National Environmental Policy Act of 1969 is applicable to land management agency actions since removing the material will have an environmental impact.

\section{The National Environmental Policy Act of 1969}

The National Environmental Policy Act (NEPA) of 1969 requires all federal agencies to assess the impact that their proposed actions will have on the environment (Evans, 2007). The findings are published in environmental assessments (EA) and environmental impact statements (EIS). An EIS is required if an EA determines the "major federal action” will have a significant impact on the environment. Case law has created a broad definition of "major federal action". This has caused NEPA to become a powerful statute due to case law interpretations of its procedural requirements (Antypas and McLain, 2002). 
HFRA attempts to reduce the NEPA's required procedural requirements. For instance, it allows the use of categorical exclusions (CEs) that eliminate the need for fire risk reduction project-level environmental impact assessments. These CEs are limited to no more than 4,500 acres for prescribed burning and no more than 1,000 acres for biomass removal (Evans, 2007). Typically, NEPA requires the consideration of three alternatives (no action, the proposed action, and one more alternative). Under HFRA, WUI projects only need to consider two options. For areas within 1.5 miles of a community, agencies only need to consider the proposed action (Keiter, 2006). Assessing the environmental impact of fuel reduction treatments is important since negative ecological impacts could occur through material removal (Evan, 2008).

\section{Physical Problems with Removal of Forest Material}

One of the greatest difficulties associated with biomass utilization is effectively removing the large amounts of material (Evans, 2008). Steep slopes and poor road conditions create obstacles along with increased fuel prices for transport vehicles. The additional costs associated with transportation create considerable and detrimental effects on woody biomass utilization. Furthermore, industries need to have access to a constant supply of biomass. With biomass utilization dependent upon biomass removal, barriers to removal are also barriers to biomass utilization. Though important to note, ecological barriers and concerns about woody biomass removal are outside the scope of this research.

There are also a number of ecological concerns about woody biomass removal (Evans, 2008). Dead and decaying organic material such as trees and brush provide 
important nutrients for the soil. Biomass removal would result in loss of nutrients for the soil. Furthermore, soil compaction from additional extraction equipment is another factor in biomass removal. Soil compaction has an adverse effect on the run-off of water. Due to ecological concerns, five states (Maine, Minnesota, Missouri, Pennsylvania, and Wisconsin) have developed recommendations for sustainable biomass removal practices (Evans, 2008). Michigan is in the process of finalizing state biomass harvesting guidelines.

A contract is required for timber or woody biomass removal from federal lands. Historically, timber contracts sold timber removed from federal lands and service contracts were used by federal agencies to pay for services such as removing hazardous (and low value) material (Hausbeck, 2007). Ecological concerns about hazardous fuel reduction projects can be addressed in the contracting method used for a project. In fact, a hybrid of timber and service contracts, called stewardship contracting, can address multiple forest management objectives.

\section{Federal Land Agencies Contractual Methods for Management Activities}

Historically, USFS management activities centered on safeguarding the nation's timber supply (Bosworth and Hutch, 2007). Prior to the 1980s, just two policy tools were used to remove material (including timber) from National Forests. These were timber and service contracts. Timber contracts are authorized under the National Forest Management Act. They are straightforward, detailed documents that specify exactly how timber can be purchased and harvested. Service contracts, also known as procurement contracts, are authorized through the Federal Acquisition Regulations and are utilized by all federal 
agencies (Hausbeck, 2007). Service contracts are simply a tool for federal agencies to purchase goods or services from the public. USFS service contracts can be used for forest restoration actions like tree-planting and recreational trail maintenance (Gorte, 2001). This straightforward action of buying goods or services allows for oversight and congressional control since Congress authorizes and appropriates agency budgets. However, as land management activities began to shift away from traditional timber extraction activities to more diverse restoration and ecological activities, timber and service contracts became limiting and cumbersome (Mitosis, 2001). In the mid-1980s, Congress authorized the BLM and USFS stewardship contract test projects (Hauselback, 2007). Due to the success of these test projects, stewardship contracting legislation was authorized first in 1999 and reauthorized in 2003. This legislation allowed agencies to engage in stewardship contracts at their discretion. Between 2003 and 2007, they successfully implemented 535 stewardship contracts (GAO, 2008). The legislation expires in 2013 (Hauselback, 2007; GAO 2008).

Stewardship contracting or goods-for-services contracting represents a fundamental shift in the contracting methods of the federal land management agencies. Instead of selling a government good (timber sales) or purchasing a private service (service contracts), goods-for-service contracts were designed for ecological restoration work, which provided a benefit to both the local community and the USFS or BLM. Value is believed to lie in combining traditional timber extraction with ecological restoration or improvement activities. Essentially, a purchaser would perform a service, such as removal of hazardous fuel material, thinning small diameter material, or 
improving wildlife habitat, and in return, would not be required to pay the full monetary amount for harvested timber (Gorte, 2001 and Hauselback, 2007). This is because a good (merchantable timber) is exchanged for a service (ecological restoration).

Goods-for-services contracts contain three unique provisions that significantly differ from traditional timber sales and service contracts (Hausbeck, 2007). First, the agencies are authorized to use end-resulting contracting. Simply put, the agencies indicate the end result they desire and allow the contractors to use their discretion to complete projects. For instance, instead of specifying exactly how a new drainage culvert would be placed, the contract merely states the end result: a new drainage culvert. End result contracting is a way for agencies to have more flexibility in meeting final project goals. Second, agencies choose projects and contractors based on "best value" as opposed to the lowest bidder. "Best value" refers to selecting a project, which will have the "greatest overall benefit" for not only the forest, but also the community as well (Hauselback, 2007 pg. 41). Therefore, factors such as past experiences with the contractor and the ability of a project to aid in rural development and economic goals are considered. The third stewardship contracting provision is the ability of the local land management agency to retain excess revenue acquired from a stewardship contracting project. The Treasury department receives revenues from a timber sale, while revenues from stewardship contracting projects can remain with the local agency for local use. Excess revenue occurs when the value of removed material is greater than the cost of contractor services.

Removing woody biomass from federal lands is impacted by the policies and 
contractual methods previously described. These treatments result in material that has potential for utilization. The utilization of removed material is encouraged, partially, through different state policies.

\section{State level incentives}

State renewable portfolio standards (RPS) are increasing demand for biomass by mandating the use of renewable sources of energy. An RPS mandates that a certain percentage of a state's electricity originate from renewable sources by a specified future date. As of June 2007, twenty-three states and the District of Columbia had renewable portfolio standards, with fourteen other states considering similar legislation (Bryne and Hughes, 2007). All of the states consider woody biomass to be a renewable resource (forestsandrangelands.gov, 2008) though definitions differ with regard to the source of woody biomass. For instance, some state RPS definitions do not credit woody biomass removed from standing forests. Furthermore, forty-one states have some variety of policies or programs focused on promoting renewable energy and energy efficiency (Bryne et al., 2007). The movement to mandate state RPSs has created regional coalitions

of states based on diversifying their power supply with resources from neighboring states. Most RPS's allow the purchase of either credits or renewable energy from other states (Bryne et al., 2007). Several conversion pathways exist to capture the energy in wood.

\section{Renewable Energy}

With rising fossil fuel prices, the idea of energy independence appeals to many Americans. Wood can be converted to energy in several ways. Conversion pathways include: 
Direct Combustion- Direct combustion is the burning of wood and woody residues. This is the most common way to convert woody biomass to energy (Ekstrom 2007). This includes traditional woodfuel (i.e. split logs in open-pit fires or basic wood stoves), charcoal, wood pellets, and residues from industrial timber production used for heat and/or electricity. Wood chips are a popular option for small scale heating operations. Globally, wood pellets are increasingly used for household and industrial heating/energy needs. Pellets are small, compacted circular pellets made from forest industry waste such as sawdust, wood shavings, and wood chips. Due to their small size and compact nature, pellets are easily transported and provide more energy per unit volume than unprocessed wood. Demand for pellets continues to grow especially in European countries with strict renewable energy requirements (Ekstrom, 2007).

Utilizing wood energy from manufacturing residues is a common practice. Over $98 \%$ of all mill residues are used for energy or to make other products (like pellets) (Walsh et al, 2007). Heat and/or electricity are provided to mills through boiler systems in which waste residues are combusted and either heat is created to warm buildings or steam is used to power turbines for electricity. Producing both heat and power is termed “cogeneration”.

Co-firing - Co-firing is the process of mixing biomass with fossil fuel to fuel a boiler (Hughes, 2000). In the case of coal, woody biomass helps to reduce sulfur dioxide emissions allowing manufacturers to reduce greenhouse gas emissions.

Gasification and Pyrolysis - Pyrolysis and gasification uses a mixed feedstock of bark and clean (bark free) wood chips (Kneeland and Perlis, 2008). Gasification is a 
process in which woody biomass is heated in the absence of oxygen until a synthetic gas (syngas) is created. This syngas has many of the properties of natural gas and can be used to power engines, turbines, and fuel cells. Syngas can also be further manipulated for fertilizer production. Pyrolysis results in a "pry-oil” product which can be used like crude oil. The forest products industry frequently uses liquid forms of wood energy. For instance, black liquor, a papermaking byproduct, is burned in specialty boilers to provide pulp mill heat and power. Gasification and pyrolysis can also produce wood-based transportation fuel. 


\section{Chapter 3. Scholarly Literature Review}

Woody biomass utilization is in a unique position to meet renewable energy, wildfire prevention, and climate change mitigation goals. It is important to recognize the conflicting and complementary elements associated with these three potential roles of woody biomass utilization (USDA, 2008). Two main policy spheres impact U.S. woody biomass utilization: fire policy (tied to public land policy) and bioenergy policy (tied to economic policy, especially in this case, in the form of rural economic development policies). Woody biomass utilization can facilitate both wildfire mitigation and bioenergy development.

\section{Woody Biomass Utilization as a Wildfire Mitigation Tool}

Woody biomass is a by-product of logging and timber management activities. In recent years, the federal government has promoted the removal of woody biomass as a way to reduce the risk of hazardous and catastrophic wildfires (GAO, 2006; McKee, 2004). Low-value brush and small diameter tree removal occurs on public lands at all levels of government. Five federal agencies (USFS, BLM, National Park Service, Fish and Wildlife Service, and Department of Defense) manage the majority of public lands in the United States. Since thinning activities can be expensive, the federal government uses different strategies to create markets for the thinned materials. These markets can aid in meeting rural economic development goals, though, with limited success to date (Moseley and Toth, 2004). However, with an estimated 90 to 200 million acres of U.S. forestland needing fuel reduction treatment, great potential for woody biomass utilization 
exists (Keiter, 2006).

In the last 50 years, U.S. public land management policy shifted from extraction oriented toward a more holistic, ecosystem management approach. This shift resulted from desires to protect aesthetic qualities, wildlife habitat, and recreational opportunities (Jones and Lynch, 2002; Bosworth and Brown et al., 2007). For instance, the USFS, adopted ecosystem management through regional and landscape planning, instead of localized planning (Antypas and McLain, 2002). While “ecosystem management” is still a poorly defined term, this new approach moved agencies from focusing on what "forests should be" instead of what "forests should produce” (Antypas and McLain, 2002 p. 49).

Policies such as the National Fire Plan and HFRA attempt to reverse damage to forests caused by fire suppression. Fire policies in natural resource management have evolved through time from a mandate of complete suppression to recognition of its ecological importance (Dale, 2006). However, after years of fire suppression, the catastrophic wildfire risk is too great to let overstocked stands simply burn (Keiter, 2006). These policies attempt to create a healthy forest. However, the term "healthy forest” is a value-laden term open to interpretation (Salka, 2004; Warren, 2007). The value individuals place on timber production versus forest preservation influences their view of a "healthy forest" (Warren, 2007). These perception differences could help explain increased litigation in areas where the public perceives land management agencies as “tampering” with the forests (Laband et al., 2006 pg. 484).

Federal fire policy is a loose conglomeration of federal policies, statutes, and directives (Keiter, 2006). The National Fire Plan brought more interaction between state, 
federal, and local actors in controlling wildfires, while recognizing the importance of natural fire in ecosystems. Risks are associated with fire as a management tool. For instance, if fire is used as a management tool and the managers lose control of the fire, people who suffer damages are not eligible for compensation from the Burned Area Emergency Rehabilitation Fund (Dale, 2006). This makes land managers reluctant to use prescribed fire. Additionally, a wildfire must be suppressed in an area that does not have a formal Fire Management Plan that meets National Fire Plan specifications (Dale, 2006). Additionally, land management agencies are required to report "acres treated” for hazardous fuel reductions. However, places in which prescribed burns occur do not count towards "acres treated". This is recent policy change mandated by the Office of Management Budget (Dale, 2006), due to the concern with “double-counting” acres which can occur if prescribed burning and mechanical thinning happen on the same area. This policy provides no incentive to utilize this effective tool to reduce overly dense understory growth (Dale, 2006). The focus on administrative rather than ecological targets has led to criticism of the USFS. A National Forest's budget is believed to be inextricably tied to “acres treated” (Dale and Gerlack, 2007). Organizational constraints, as described above, led to increased spending for fire suppression without a decrease in acres burned due to unplanned wildfires. This has agencies caught in a situation where they react to problems instead of preventing them (Dale, 2006). In an attempt to prevent problems, federal funding was targeted for hazardous fuel reduction projects in the WUI (Dale and Gerlack, 2007).

In 2003, the Healthy Forest Restoration Act (HFRA) reframed the fire problem as 
a litigation problem. HFRA focused on hazardous fuel reductions strategies and was "the first serious congressional effort to articulate a federal fire policy” (Keiter, 2006, p. 312). Fifty percent of appropriated funding through HFRA is spent on WUI projects (Dale and Gerlack, 2007). With a growing emphasis on fuel reduction in the WUI, management emphasis is place at local instead of regional or landscape levels (Field and Jensen et al., 2005).

Communities create community wildfire protection plans (CWPP) in order to be eligible for HFRA funds. CWPPs' main goals are to add transparency to land management decision and gain community support, while reducing localized fire risks (Keiter, 2006). Formation of a CWPP requires collaboration between a community and federal land managers. This can reduce adversarial relationships between federal agencies and commuinities. Furthermore, incorporating affected community members in the decision-making process can create stronger community support for public land management activities (Skogen, 2003). This is important because the urgency of controlling catastrophic wildfires is not always perceived at the local level. This highlights the need for effective communication between federal agency personnel and local community members since, in order for wildfire policies to be effective, community members need to believe there is a wildfire problem (Burns et al., 2007).

Hazardous fuel reduction can occur through thinning, prescribed burning, brush removal, and/or livestock grazing. The use of these different techniques is greatly influenced by the specific location of the activity and the area's social and environmental attributes. Therefore, federal land managers face challenges attempting to adhere to 
national strategies and mandates while balancing local needs and values (Brunson and Shindler et al, 2004). Hazardous fuel reduction management has been met with resistant by some communities who view it as an excuse to increase logging on public lands (Keiter, 2006).

With the rapidly growing WUI, increasing numbers of homeowners are vulnerable to wildfire risk. However, this may be difficult to convey to landowners thereby making it challenging to convince them to reduce fire risk on their properties (Martin, 2008). However, understanding how the public perceives the affects of fire can lead to better community-supported decisions (Kneeshaw et al., 2004). For instance, the USFS has adopted a strategy of allowing some naturally started fires to burn. While "letburn” policies for natural fires have some public support, there is little support for allowing fires started by humans to burn.

Public land managers can gauge public concerns about fire management by gauging how the community would perceive potential impacts on structures, air quality, and recreation (Kneeshaw et al., 2004). This is important since negative perceptions towards agency fuel reduction activity can lead to an increase in time-consuming litigation. Litigation can be avoided and better decisions can be made if agencies can gain community support by building trust and explaining how fuel reduction protects communities (Vogt et al., 2005). Public beliefs about management are greatly influenced by beliefs about personal impacts, especially for WUI homeowners (Vogt et al., 2005).

A “win-win” situation for agencies and communities is to incorporate bioenergy and/or small-diameter wood utilization into a hazardous fuel reduction project. Thinning 
project costs are offset and local jobs created if markets for removed material exist (Nechodom et al., 2008).

\section{Bioenergy and Small-Diameter Utilization of Woody Biomass}

Materials from fuel reduction treatments can be used in one of two ways, for bioenergy or solid wood products. However, utilization depends heavily on other regional characteristics such as the state of the existing wood products industry. For instance, small diameter material can be used for relatively high value-added products, such as posts and poles or narrow-width lumber. Integrating these products, with commercial saw-timber harvests, is often associated with a lower initial cost relative to biomass production (LeVan-Green and Livingston, 2001).

Biomass production, which often includes chipping material for bioenergy, tends to utilize more material but results in lower profits due to higher operating and removal costs (Lowell et al., 2006). In fact, transportation and harvest costs are typically greater than biomass market values (Mason et al., 2006). Therefore, converting wood to energy is a more capital-intensive and expensive process than solid wood production (Lowell et al., 2001).

Public and private entities utilize wood for energy production at state and local levels. It is critical to invest in the end use of biomass removed from hazardous fuel treatments in order to control treatment costs (Becker et al., 2009). Especially, since in many areas the scale of available infrastructure to utilize material from hazardous fuel reductions does not complement the scale of available material (Becker et al., 2009). 
The high costs of fossil fuels, especially home heating oil, create a market for wood energy. Government sponsored woody biomass utilization activities try to connect into this demand in order to recoup some of the costs of hazardous fuel reduction treatments. Federal grants for biomass utilization are important and considerable federal funding has been made available through the Biomass Research and Development Act of 2000, the Energy Policy Act of 2005, and through the U.S. Forest Service community assistance programs (Nechodom et al., 2008).

Success can occur when projects, funded with federal grants, are clustered together so benefits can be shared (Becker et al., 2009). Two major concerns exist with projects that depend on federal grants. First, smaller projects are favored due to short funding cycles since local organizations often do not have the administrative capacity to manage large multi-year grants. These two issues hinder long-term projects. Organizational constraints of grantors and grantees hinder larger multi-year projects, which could benefit local areas (Becker et al., 2009). Landscape or regional scale usage of woody biomass utilization will require large multi-year projects. Wood-based bioenergy has great potential since it is technically feasible, though economically difficult, to co-fire biomass with coal (Hughes, 2000).

Nearly $50 \%$ of electricity in the United States is obtained from the use of coal (EIA, 2007), and biomass can be used to displace up to $15 \%$ of coal in power plants. This strategy, termed co-firing, is gaining popularity in Europe as a way to meet carbon dioxide reduction criteria (Peska-Blanchard et al., 2007). In the United States, the lack of economic (financial) incentives results in minimal electricity production from biomass 
(Hughes, 2000). Specifically, the lack of a market or policy tool to capture the cost of carbon dioxide emissions limits the incentives to find alternative feedstocks for electricity production (Hughes, 2000).

Encouraging WBU requires more than favorable economic factors. Social, political, and environmental factors are also important in promoting and crafting successful bioenergy projects. This is partly due to differences in policy objectives at the local and national levels. For example, job creation is likely to have higher perceived value than climate change mitigation at the local level (Domac et al., 2005). Job creation is often the most noticeable impact of bioenergy at the local level (Gan and Smith, 2007). At this level, contributions of bioenergy to climate change policy goals are a co-benefit, in addition to rural economic development (Domac et al., 2005). Therefore, it is important to recognize the different social benefits of bioenergy at different scales of society (Domac et al., 2005). Social factors can influence bioenergy development at the local level more than technological or ecological factors (Iverson and Van Demark et al., 2005). This is because successful public participation and community involvement is required to implement bioenergy projects, especially if public lands are involved (Farnsworth et al., 2002; Iverson and Van Demark et al., 2005).

\section{Public participation, wildland fire management, and bioenergy}

As wildland fire management activities blur with local, state, and national bioenergy requirements the importance of policies that incorporate public participation, prove critical. This is because policy decisions are fundamentally values choices based on technical information (Creighton, 2005). The quality of decisions can be improved 
and organizational credibility can be maintained and improved with adequate public participation. Further benefits include avoiding the costs associated with sensitive confrontations and extensive litigation (Creighton, 2005). Public participation can take many forms, ranging from educational programs to activities, which incorporate local decision-making capabilities, such as CWPPs. However, the overarching theme and criteria of public participation is the need for interaction between all stakeholders. The most effective forms of public participation are not passive, one-sided events or programs, but interactive situations that focus on collaborative processes (Creighton, 2005). 


\section{Chapter 4. Research Design}

My research goal was to understand how WBU project participants believed state and federal policies were facilitating or hindering woody biomass utilization. I used data collected from in-depth interviews with individuals who have a firsthand perspective on woody biomass utilization. These interviews were part of a project, funded by the Joint Fire Science program of the Bureau of Land Management (BLM) and the USDA Forest Service (USFS), to understand barriers and strategies for fire risk reduction-related woody biomass utilization. The purpose of the larger study was to provide a summary of "lessons learned" for land managers in other parts of the country with regard to woody biomass utilization. Interviews were comprised of a mix of individuals involved with biomass utilization on tribal lands, at nongovernmental organizations (NGOs), industry representatives, and employees at all levels of government. These one hundred twenty-six in-depth interviews were conducted from September 2007 through September 2008. These interviews represent ten case studies from various regions of the country. The case studies include:

- Northern California - Ten interviews revealed a complex story centered on the different roles of the 2.1 million acre Shasta-Trinity National Forest in tourism, recreation, and forest product production. Biomass removal was critical due to the risk of catastrophic wild fire; however, challenges to biomass removal included the risk of project litigation and navigating steep and difficult terrain to remove biomass. 
- Front Range of Colorado - The Front Range of Colorado refers to the part of the Rocky Mountains where a westbound traveler first encounters the mountains in Colorado. This area in north-central Colorado contained a considerable amount of the state population and major cities. The Mountain Pine Beetle (MPB) epidemic increases tree mortality and therefore increases the risk of wildfire. Additionally, this area contains a rapidly growing Wildland-Urban Interface (WUI). While the concern about wildfire is great, the lack of a well-formed forest product industry in the Front Range results in low demand for woody biomass.

- South-central New Mexico - This case focused on the reservation land of the Mescalero Tribe and the adjacent Lincoln National Forest. The risk of wildfire, especially in the wild-land urban interface, is of great concern to community members. Very strong local and tribal governments influence this isolated area in New Mexico. For instance, a local ordinance in the town of Ruidoso required landowners to remove hazardous forest fuel loads on their property or receive an increase in property taxes. The city council and community approved and supported this tax.

- Coastal South Carolina - This study focused on the Francis Marion National Forest and the Sumter National Forest. In 1989, winds from Hurricane Hugo leveled many forests. The re-growth from that event contained a significant amount of small diameter trees and woody shrubs, which posed a fire risk. Prescribed burning worked well in this part of the country. Additionally, large paper mills in the area created considerable demand for wood chips. The mills 
- Southwestern Oregon - This case study focused on woody biomass utilization activities on the Rogue River-Siskiyou National Forests and BLM lands in southwestern Oregon. Oregon has a unique series of state tax incentives for the manufacturing, transportation, and production steps in WBU. This case study highlighted the difference in management styles and operational barriers between the USFS and the BLM. For instance, the USFS struggled with litigation to a greater extent than the BLM.

- Central Oregon - This case study centered on reservation land of the Confederate Tribes of Warm Springs, Deschutes National Forest, and BLM lands encompassing over 2.6 million acres of land. State tax incentives promoted woody biomass in this case as well. Major initiatives in this area included a proposed $20 \mathrm{MW}$ (megawatt) power plant utilizing biomass as a feedstock. Supply from federal lands was an issue in this case. Many smaller industries, such as animal bedding producers, did not rely on or use biomass from federal lands since the supply was unreliable and inconsistent.

- Southwest Colorado - This case focused on the San Juan public lands consisting of 2.5 million acres of co-managed Forest Service and BLM land in the southwest corner of Colorado. In 2002, a major fire swept through this area. As a result, partnerships were formed addressing biomass utilization to reduce the risk of catastrophic wildfires. Perhaps the greatest challenge for this area was the remoteness of most of the lands. The nearest sawmill requires required over one 
- Bitterroot Valley, Montana - This case study examined WBU on the Bitterroot National Forest and surrounding areas in west-central Montana. Wildfires, drought, and MPB effects are major concerns for community members in this area. Several state programs promote WBU in Montana. This includes programs that provide financial incentives for public buildings to convert to wood heat. Historically, industry in this area focused on large-diameter saw logs production. This case study highlighted the possibilities of woody biomass utilization for a wide variety of goods and services.

- Northeast Minnesota - This case study focused on biomass utilization activities within the Superior National Forest in the "arrowhead" region of northeast Minnesota. The "rush" in this area to build wood pellet plants and bio-refineries created concern about demand increases especially if competition for woody biomass developed between the pulp and paper sector and the bioenergy sector. Furthermore, Minnesota was first in the nation to implement biomass harvesting guidelines in order to address the ecological implications of woody biomass removal.

- Green Mountain, Vermont -This case study focused on the Green Mountain National Forest in Vermont and the biomass energy plant located in Burlington. In this area of the country, woody biomass utilization is fully integrated into the wood products industry, so much so, that wood chips for energy are worth more 
A more in-depth description of the various case studies is located in Appendix A.1.

Table 1 presents interviewee organizational affiliations by case.

\begin{tabular}{|c|c|c|c|c|}
\hline & \multicolumn{4}{|c|}{ Number of Interviews } \\
\hline & $\begin{array}{l}\text { Public Land } \\
\text { Management } \\
\text { Sector } \\
\text { (Government) }\end{array}$ & Industry & $\begin{array}{c}\text { Nonprofit } \\
\text { (Other) }\end{array}$ & Total \\
\hline Northern California & 6 & 1 & 3 & 10 \\
\hline Central Colorado & 8 & 2 & 1 & 11 \\
\hline South-central New Mexico & 8 & 3 & 0 & 11 \\
\hline Coastal South Carolina & 8 & 3 & 1 & 12 \\
\hline Central Oregon & 8 & 3 & 3 & 14 \\
\hline Southwestern Oregon & 7 & 5 & 3 & 15 \\
\hline Southwestern Colorado & 20 & 0 & 0 & 20 \\
\hline Bitterroot Valley Montana & 9 & 1 & 4 & 14 \\
\hline Northeastern Minnesota & 7 & 3 & 2 & 12 \\
\hline Central Vermont & 3 & 3 & 1 & 7 \\
\hline Totals & 84 & 24 & 18 & 126 \\
\hline Total Interviews (\%) & $67 \%$ & $19 \%$ & $14 \%$ & \\
\hline
\end{tabular}

The majority of interviewees worked for government land management agencies. The category "nonprofit/other” includes nonprofit organization workers and individuals who technically work for a government organization, but are not involved with public land management. This mostly applied to a handful of interviewees with regard to the “Fuels for Schools” project, such as a custodian who maintained a school’s boiler.

The semi-structured interviews followed a standard set of questions, but interviewees could expand on topics or raise new ones, as they felt necessary. Interview questions were asked about the interviewee's role and capacity in WBU followed with 
questions about current WBU activities. Questions were asked about challenges and opportunities for WBU and how those challenges and opportunities were acted upon. Interviewees were specifically asked about the scale of WBU activities, ecological constraints, and economic development opportunities. Finally, questions about the future of WBU activities were asked. Therefore, the interviews captured activities beyond the technical aspects of biomass removal and instead focused on the utilization of woody biomass. Utilization included activities associated with electricity production, heat production, and forest products, as well as non-energy products like animal bedding and landscape mulch. (Refer to appendix A.2 for the full list of interview questions.) As part of the larger project, the transcribed interviews were sorted according to the interview questions. I focused on coding and analyzing responses to question fifteen and its sub-components which state:

“15a. What contributes to the agency’s ability to encourage utilization? What could the federal agencies do better to facilitate utilization?

15b. What kinds of agency factors contribute to their ability to partner with communities?

15c. Which state and/or federal policies/credits/practices best facilitate biomass utilization? Why?

15d. How well have the different authorities/mechanism used, worked?” In the transcribed interviews, I looked for instances where question 15 was 
answered or asked and then labeled that section of text with a unique code comprised of the interview number followed by Q15 (For example, places question 15 was asked or answered in interview number 1 received the label “I1Q15”). Once all the interviews were labeled in this manner, the section of text related to the label was extracted and placed into a new document. This was done on a case by case basis. The responses to question 15 were placed into a single document. At this point, I developed a series of codes in relation to federal policies. Specific policies were given a unique code. Examples of the codes include "F1" for The National Fire Plan and "F5" for stewardship contracting.

Many interviewees discussed state policies which hindered or promoted woody biomass utilization. Therefore, a state specific code was used to label state policy discussions. Furthermore, many interviewees reported barriers to woody biomass utilization, which could have been due to a specific policy, yet did not mention a specific policy. In cases such as this, I labeled and identified which agency the interviewee discussed and labeled the barrier. Most interviewees focused their responses on the United States Forest Service and the Bureau of Land Management. After this step, I then analyzed the coded responses by carefully counting how many interviews mentioned a specific policy and whether the interviewee believed that policy was aiding or hindering woody biomass utilization. All the coded information was combined to look for trends and patterns across all case studies. My results highlight four key areas: federal policies, state policies, agency (organizational) barriers, and potential future policies. 


\section{Chapter 5. Results}

I set out to determine whether WBU participants believed federal and state policies were aiding or impeding biomass utilization. Overall results suggest specific policies neither overwhelmingly impede nor facilitate woody biomass utilization. Rather, the context in which the policy is administered seemed to have had the most impact on its usefulness or lack thereof. Fifty-three (42\%) interviewees described some form of organizational barrier due to a land management agency's actions with regard to woody biomass removal and/or utilization. Out of the one hundred and twenty six interviews analyzed for this study, only ten interviewees made no mention of any type of policy influence with regard to woody biomass utilization. Therefore, 92\% of interviewees discussed policy impacts in some form.

My analysis is presented in four sections in this chapter, based on the frequency

of interviewee responses. First the interviewees’ viewpoints on the most discussed public land policies are presented, followed by a discussion about organizational barriers to successful implementation of these policies. Next, results with regard to state policies are discussed. Finally, I describe miscellaneous issues that highlight a few key trends.

Interviewees were asked a variety of questions about their experience and current perceptions with WBU activities. My research focused on responses to question 15 in the standard interview guide (Please see Appendix A.2 for the full interview guide). Question 15 elicited responses about federal and state policies that encourage woody biomass utilization. 


\section{Federal Policies related to Woody Biomass Utilization}

Chapter Two presented background information on four major federal policies (National Fire Plan, HFRA, NEPA, and stewardship contracting). Out of these four main policies, eighty-one (64\%) interviewees discussed at least one of these specific policies. Generally, these interviewees mentioned a federal law, by name, in passing. Typically, they would list a federal law to provide a timeframe for their account of management activities.

Of these interviewees, more discussed their perceptions and attitudes toward stewardship contracting and NEPA, but not towards the National Fire Plan and HFRA. At least three interviewees from every case study referenced one or more of these policies. The most discussed federal policy was stewardship contracting. Sixty-two (75\%) interviewees who specifically mentioned one of the above policies were government employees. Detailed results for the National Fire Plan, HFRA, NEPA and stewardship contracting are presented next.

\section{The National Fire Plan}

Twenty-three (18\%) interviewees discussed the role of the National Fire Plan in projects related to hazardous fuel reduction. Frequently, the interviewees mentioned funding received through the National Fire Plan, such as for a Fuels for Schools project, or greater attention to the risk of wildfires due to the National Fire Plan. For instance, hazardous fuel reduction treatments are encouraged through an increase in federal funding. As two government employees explain, 
Interviewee: Incentives? Well you know, I think the National Fire Plan did that. We [National Forest] were given dollars per acres to actually do something on the ground, where in the past we were struggling to try to do it with the timber sale. So, I think that was an incentive (Interview 101)

And,

Interviewee: Well, having the funding through the National Fire Plan has really helped. That was a good jumpstart (Interview 32).

Several interviewees referenced past catastrophic wildfire events as precipitating the need for or creation of the National Fire Plan. In general, the NFP was viewed by interviewees as bringing needed attention to the threat of wildfires and promoting treatment of forests. As a government employee states,

Interviewee: we had a large fire season in 2000 and in part I think the National Fire Plan was developed as a result of what happened here. But, a component of the National Fire Plan dealt with biomass utilization and figuring out a way to promote not only the massive amounts of material that were burned but also and more importantly getting out ahead a little bit in terms of reducing hazardous fuels. And a key part for a forest management perspective in terms of being able to reduce hazardous fuels is having some ability for that material to pay for itself at least eliminate some of the [removal] costs so it's not so expensive... Since about 2000 we just formed a really productive community group that's kind of tackled that issue (Interview 125).

Interviewees perceived the NFP as a source of increased funding for hazardous fuel reductions. This funding promotes woody biomass utilization through the creation of community groups which create and administer programs to use the NFP funding. In quote 125, the community group formed was ultimately responsible for implementing Fuels for Schools projects in the State of Montana. Fuels for Schools are not a federal policy per se, but outcomes of state and local organizations use of federal funding. In my 
research, Fuels for Schools projects were only discussed in the Montana case study and I will present findings about that program in the state policy section.

\section{The Healthy Forest Restoration Act and CWPP}

Ten (8\%) interviewees mentioned the Healthy Forest Restoration Act by name. Another ten interviewees discussed the implementation of Community Wildfire Protection Plans (CWPP), which allowed communities access to additional funding under HFRA. Therefore, twenty (16\%) interviewees mentioned either HFRA and/or the HFRA-created CWPPs. Five of the interviewees told us that HFRA was beneficial for forest management practices as it helped protect communities from wildfires. However, these interviewees viewed biomass production and utilization as more of a by-product or secondary goal of hazardous fuel reduction rather than a primary goal. As one interviewee stated,

Some of the healthy forests initiatives, HFRA, and things like that probably have more influence on biomass in a sense that the federal government has committed itself to some degree to finance and pay for hazardous fuels reduction. As a side benefit of working in wildland urban interface areas to try and reduce the fire hazard we are generating biomass in many cases. (Interview 129)

Interviewees associate reducing barriers with HFRA. For instance, HFRA includes a provision where smaller projects can "opt-out” of NEPA requirements. Four California interviewees mentioned that the $9^{\text {th }}$ District Court took that option away. They viewed this restriction as a barrier. Three expressed concern that a decision would be litigated when a categorical exclusion, exempting a project from NEPA requirements, is used. Additionally, they discussed the lack of available staff to implement HFRA. As one interviewee stated, 
The forest has been - we're kind of behind. We're starting to get some pressure from the timber industry, we have not a single HFRA EIS on the [National Forest], not yet because I don't think our line officers or practitioners are sold on the fact that it's going to benefit us on the timeline. There's an assumption that your litigants are willing, that there are some abilities to do some consensus building and that you can design a resolution, our experience is not that. (Interview 9)

Ten (8\%) interviewees discussed the implementation or role of CWPPs in their community. One interviewee reported that most of the CWPPs in California were written by retired USFS personnel. Similarly, to the National Fire Plan, HFRA, and CWPPs were often referenced as a timeframe for completed actions. However, CWPPs were seen as a positive thing since they seemed to encourage project completion and attracted additional funding. Views on HFRA were split with several interviewees commenting on the lack of available funds and time to learn a new law. Other interviewees felt the HFRA was beneficial because, similar to the National Fire Plan, it brought attention and funding to a problem.

\section{The National Environmental Policy Act}

The National Environmental Policy Act (NEPA) requires federal agencies to consider the impact of their actions on the environment. Thirty-one (25\%) interviewees mentioned NEPA specifically by name. Twenty-one (17\%) interviewees expressed concern about the time, manpower, and legal challenges associated with NEPA compliance. Three interviewees felt that procedures for adhering to NEPA were too timber-oriented. Eleven (9\%) interviewees discussed various strategies for adhering to NEPA, while successfully completing biomass projects. Strategies explained by one county-level land manager and one U.S. USFS employee, respectively, include: 
We've begun to work ourselves away from diameter limits as just a way to make the NEPA bulletproof, or at least not have people challenge them... (Interview 5)

A project that removes large diameter trees is more likely to have its NEPA documents legally questioned due to concerns about old-growth harvesting. As several interviewees mentioned, the public generally does not like to see large trees harvested. However, "large" is relative. Public land managers try to determine "acceptable” diameter limits to avoid litigation on projects. Another example of reducing the risk of litigation is to, initially, file a more time-intensive environmental impact statement instead of an environmental assessment. As one interviewee explains,

Interviewee: ....Most of our projects now are EIS's, [environmental impact statements] huge change, and that's within the course of 3 years. Went from mostly environmental assessments to now EIS's, and much of that is actually based on the likelihood of us prevailing when we get challenged in court.

Interviewer: So it's bullet proofing, sort of?

Interviewee: Sort of. It's at least putting the flak jacket on. So I think the quick statistics I remember are that, when challenged, if we have an environmental assessment that we go to court with, we have a 2/3 likelihood of not prevailing. And EIS, it's more like a 2/3 likelihood of prevailing, so.

Interviewer: How's the timeframe different, in terms of putting together an EA [environmental assessment] versus an EIS?

Interviewee: Hypothetically, it should only be about 6 months to a year's difference. In real life, I think it's closer to a year, year and a half difference.

Interviewer: Because?

Interviewee: Just the complexity of the documents. (Interview 10) 
Typically, an environmental assessment is the first step in the NEPA compliance process. If a proposed action is determined to have a "significant impact" then a much more detailed environmental impact statement is performed. As the interviewee explained, an EA was much more likely than an EIS to lose in litigation. Time could be saved by skipping the environmental assessment, performing the environmental impact statement, and hopefully avoiding litigation or a loss in litigation.

Other strategies for reducing NEPA barriers include placing projects in "shelfstock”. As one interviewee explained, this meant performing NEPA on projects with the hope of receiving future funding for the project. In this way, projects could begin as soon as funding was secured. One interviewee reported performing management activities on projects which were already NEPA-cleared. Two interviewees reported on increasing public acceptance of projects by carefully choosing their wording to describe the project. They suggested using terms such as “fuels reduction” instead of “timber sale” or “removal”. This strategy was meant to avoid public disapproval and litigation. Lastly, two interviewees reported NEPA compliance was not a problem in their area because the public was supportive of thinning activities. Overall, 55\% of interviewees who mentioned NEPA felt it was a hindrance to management activities due to time constraints from litigation and additional staffing needs.

\section{Stewardship Contracting}

The most frequently mentioned policy overall was stewardship contracting. Fiftyseven (64\%) interviewees mentioned stewardship contracting. Thirty-four (27\%) interviewees believed stewardship contracting functions have positive impacts and 
aids in woody biomass utilization. As a timber industry representative from Oregon states:

As of lately it's probably the best opportunity on National Forests I've had in years. It's working, it's a good tool for the USFS to get projects done, it melds service with timber sale, it keeps those dollars local, it's got a lot of good goals. Promote local economy, get people to work in the forest, the jobs it's created just under my contracts, the truck drivers, the guys operating my machines, the men on the jobs that are earning a family wage with benefits and retirement. The more we can do the better off it is, the stewardship contracting allows latitude, larger scale, it's getting work done in the forest. I think it's been a great tool for the USFS (Interview 68).

Four interviewees specifically stated stewardship contracting provided much more flexibility for biomass management options, which increased biomass utilization in a “gradual, but positive direction” (Interview 131). One described stewardship contracting as the "best" tool for forest management since public land managers "can focus more on all the other reasons for managing land, whether it’s wildlife, fire, watershed....” (Interview 85). One noted that the stewardship contracting legislation expires in 2013 and should be renewed. Five interviewees discussed the ability of stewardship contracting to achieve multiple goals, such as watershed restoration and local job creation.

Local job creation was mentioned as a way to gain community support for stewardship contracting projects. The benefit of local jobs to the community seemed to outweigh the benefits of the revenue sharing from timber sales (Interview 10). Two Bureau of Land Management (BLM) employees use stewardship contracts only after the county commissioner approved the project. The county commissioner's approval was not necessary, but increased goodwill and allowed for community "buy-in” of stewardship 
contracting projects. This is especially important in areas where communities receive a share of timber sale revenue.

Eight interviewees told us that stewardship contracting was especially useful in situations where it was not economically viable to remove material. Furthermore, a longterm stewardship contract equaled a steady supply of material. This steady supply allowed loggers easier access to bank loans since they were "guaranteed" to be in business for the length of the stewardship contract (Interview 32). Four interviewees said that they would like to use long-term stewardship contracting, but were currently unable due to barriers associated with stewardship contracting as described in the next paragraph.

While thirty-four interviewees (27\%) believed stewardship contracting was helping or could aid in woody biomass utilization, twenty-six (21\%) reported problems with stewardship contracting. These problems or barriers included the complexity of contracting documents, local unfamiliarity with stewardship contracting, and internal resistance from public agencies to utilize stewardship contracting. One USFS interviewee highlighted some of the issues with stewardship contracting:

Interviewer: Do you have any stewardship?

Interviewee: For biomass? Right now, the stewardship [contracting] isn't working... I shouldn't say it isn't working, because we are pursuing it. Because we need to see if we can utilize the tool. But, I think stewardship [contracting] works the best when a local entity, community, whatever, has a need and we can strive together to meet that need...Right now, biomass isn't a local need. Fuel reduction is. And reducing the cost of fuel reduction is... And, we're just kind of taking baby steps with the stewardship. Because we did try one...And I think that no one bid on it, and if they did, they bid a lot of money on it. So, we're not, we're not connecting with industry...(Interview 151) 
As one industry representative explained further:

So one of the major tools they got for doing this and the [sic] Forest Service is their stewardship contracts. But this paradigm and this transition right now is [having a] particularly tough time...The private industry is having a tough time with the sale administration on these things, to where they're getting into minor infractions that just tie them up in knots to where they can't hardly operate...That long term availability of timber is a huge one and stewardship is one of the things that can get them there. So I'd like to see more of those stewardship sales but they're going to have to change their make-up a little bit in order to get them sold. (Interview 127)

A USFS line officer expressed similar beliefs:

The [USFS] chief's office has set kind of a soft target. They want the Forest Service to pursue stewardship contracts. They think it's a good thing. They are more problematic that the standard service contract or the standard timber sale contract. They're kind of new, they're tougher to put in place, sometimes they scare the agency personnel, sometimes they scare the potential contractors... (Interview 111)

Though barriers exist, nine (8\%) interviewees reported on the ability of effective communication and flexibility in contracting terms as ways to ensure efficient stewardship contracting. For instance, one interviewee felt stewardship contracts needed the option of adjustment according to changes in market prices for biomass. Three interviewees discussed the need to change how material removed from the forest was measured from board to cubic feet in regard to measuring wood chips. Some national forests have made this change. Administrative changes, such as utilizing a new unit of measurement, provided one example of public land management agencies accommodating users of woody biomass. This shift in viewing and managing public lands warrants a discussion of some of the organizational frameworks in which policies such as the National Fire Plan, NEPA, HFRA and stewardship contracting operate. 


\section{Federal Agencies Involved with Woody Biomass Utilization}

As interviewees discussed specific policies and programs, also discussed was the organizational context in which they worked in. This led to several patterns which will be presented here. The BLM and the USFS are featured prominently in interviewee discussions. BLM representatives were interviewed for three of the cases (central Oregon, southwestern Oregon, and southwestern Colorado) while all of the cases had at least one interviewee from the USFS. The Bureau of Indian Affairs (BIA) was involved with two cases that dealt with tribal lands. Overwhelmingly, interviewees discussed the role of the USFS and, to a considerably lesser extent, the BLM. A total of sixty-six (52\%) interviewees mentioned either an organizational barrier such as agency budget cuts or, to a lesser extent, actions federal agencies were taking to increase biomass utilization. Out of these sixty-six interviews, sixty (48\%) interviewees specifically discussed the USFS.

Fifty-three (42\%) interviewees described a barrier to woody biomass removal and/or utilization they attributed to the USFS. Barriers included a lack of accessible woody material from USFS lands, agency budget cuts, high staff turnover, community mistrust of USFS, agency fear of litigation, and misdirected agency management targets. As a USFS employee said, "It's incredible the hoops you have to jump through to do any project” (Interview 2). Twenty-two (17\%) interviewees described problems with the USFS budget and/or problems with staff reductions and turnover. Seven (6\%) explicitly discussed fire suppression costs associated with fire-fighting as having a negative effect on other agency programs. One interviewee described fire suppression costs as “cannibalizing” other programs, while others saw the USFS as more reactive than 
proactive toward wildland fires. A USFS line officer summarized the issue:

So it's kind of an insidious circle in that more and more money is going into suppression, that's less and less resources either personnel wise or financially to invest in treatment, and yet the problem is getting bigger, but you're getting more and more on the reactive and less and less on the proactive, so it's a path that's not very good. You know you're going to run out of gas before you get to the gas station, and our answer is to drive the car faster (Interview 10)

One interviewee lamented the fact that his division did not even have a budget but was operating on a continuing resolution (Interview 98). Seven (6\%) discussed management targets on National Forests, while five interviewees reported targets dictate how an agency is funded. Interviewees felt "acres treated” did not correspond to "priority" acres and created perverse incentives to treat "easy” acres. As one industry representative who relied on woody biomass from public lands explained,

I think the number one thing that I see is this, on the USFS, National Forest, I'm talking the feds, is acres treated. Those targets are the biggest problem we have. It puts our line officers and our people on the forest right in a catch-22. They're not treating the acres necessarily that need to be treated, but they have this pressure, whether it's spoken or unspoken, whether it's internal or external, to produce so they can get a good grade on their report card, their performance measures...And that is not to say that the USFS doesn't want to do the job. I'm just saying that the environment is not conducive to produce priority acres... Yeah, it's not how much money did you spend, it's like how many acres did you treat for this amount of money. So it, what's driving the decision to treat the acres and the type of treatment, is not what's best for the acre. It's the number of acres that they can get done (Interview 39).

Two interviewees specifically discuss how "acres treated" lead to double counting of acres. For instance, if mechanical thinning was performed on an acre and, the following month, additional mechanical thinning occurs on the acre, this would be recorded as two acres treated. The interviewees felt this was a barrier to biomass 
utilization since it encouraged frequent site re-entries. One explained that loopholes such as this exist because the USFS is encouraged "to do more with less" (Interview 38).

Twenty-four (19\%) interviewees described supply problems as a barrier to woody biomass utilization. Reasons for lack of supply were numerous and ranged from inadequate roads to fear of environmental litigation to internal agency resistance to biomass removal. As a state employee explained,

Everything is devoted to trying to pay the fire bill, not the forest management bill (Interview 20).

Woody biomass utilization activities typically use non-merchantable (i.e. not timber or pulpwood) material. Seven interviewees (6\%) described the "timber extraction" mindset of the USFS as a barrier to woody biomass utilization. For instance, one remarked that the USFS treats green (live) timber the same as dead timber, though there is no legal mandate to do so. Another interviewee remarked that the timber market and the biomass market are very different and need to be treated as such. Three described their experience with changing the unit of measure of material from the woods as reported in the stewardship contracting portion of this research. One interviewee stated that the shift from measuring in board feet to cubic feet was "hard for some to understand" (Interview 111). Six interviewees (5\%) discussed the role of the USFS Washington Office in setting policy and targets for woody biomass utilization. Some of the interviewees felt that while the Washington Office encourages woody biomass utilization, they are more interested in policy than solving on-the-ground issues.

Ten interviewees (8\%) positively described USFS efforts to encourage and promote woody biomass utilization. This included the USFS funding of 
intermediary nonprofit groups to help facilitate woody biomass utilization. Other actions included placing harvested material in accessible locations so individuals could collect it for firewood. Funding of woody biomass utilization demonstration projects was also deemed valuable. The role of the "internal champion” was also highlighted, as often USFS personnel were "not always rewarded internally" for participating in biomass utilization projects (Interview 7 and 62).

Stewardship contracting is just one type of contractual method for encouraging woody biomass utilization. The other types of contracts used by the USFS are service contracts and timber sales. Timber sales can be written to include removal of slash and debris. Eight (6\%) interviewees reported barriers to woody biomass utilization due to service or timber contract methods. This included placing too much emphasis on saw logs and a lack of flexibility to adjusting a contract when market conditions changed.

Less frequently mentioned were BLM actions that impeded or facilitated woody biomass utilization. Six (5\%) interviewees explained that the USFS and the BLM were “different organizations” that operated independently and had different rules. As one BLM employee explained,

There's a big difference in agencies. And maybe that's the way it is between all federal agencies. But at least between the two, they have kind of co-evolved into very similar work, but they have very limited communication. So they've all developed their own methods and policies and budgeting and staffing and trucks. Everything is similar but different (Interview 89).

Typically, the BLM was described as having more success with biomass utilization due to their ability to work "under the radar". Similar to the USFS, the BLM is target-driven. However, the BLM has a policy requiring that $25 \%$ to $50 \%$ of 
material removed for fuels reduction is utilized (Interview 98). The USFS has a policy that encourages biomass utilization, but does not require it (Interview 67).

\section{State Policies and Woody Biomass Utilization}

While the initial focus of this research was federal policies and strategies, a discussion about the impacts of state policies aids in understanding the environment federal policies operate in. Furthermore, some policies and programs blur federal and state boundaries, especially when it comes to program funding.

Forty-seven (37\%) interviewees mentioned a specific state policy or program which promoted or potentially could promote woody biomass utilization. Fifteen (12\%) interviewees discussed specific state policies or programs which hindered woody biomass utilization. Often the hindrances were policies written with a perceived bias toward wind energy and solar energy. Two major themes emerge the role of state tax incentives in woody biomass utilization and the impact of state renewable portfolio standards. In addition, results related to the Fuels for Schools initiative along with other results important to individual case studies are of significance. As explained earlier, Fuels for Schools programs are local initiatives often started with federal grants. Since only one case study reported on a Fuels for Schools project, the information is included in this section.

Thirteen (10\%) interviewees mentioned state tax credits or policies which encouraged woody biomass utilization. Examples include, the City of Ruidoso's (located in New Mexico) policy to incorporate the cost of fuel reductions into local property taxes. Residents received a tax break if they certified management activity to thin 
hazardous fuel loads on their property. Additionally, in order to secure a new building permit, land had to be treated for hazardous fuels. Oregon has a Business Energy Tax Credit (BETC) which is a tax credit to offset the initial costs of renewable energy projects. Companies have the ability to sell these credits for cash if they are too small to gain from them. Furthermore, Oregon has a piece of legislation entitled House Bill 2210 that is a transportation tax credit for transporting biomass. Three interviewees described this bill as a "big deal" since it provides a biomass subsidy of $\$ 10$ per green ton for transported biomass. As one biomass industry user explained,

Without it [House Bill 2210], this material would either just sit out in the woods to be burned or it would rot out there." (Interview 83)

There is concern that the rise in diesel prices could nullify the credit (Interview 63).

Only one interviewee mentioned a state tax which negatively affected biomass utilization. This was Oregon state law changed timber tax rates. Instead of being taxed on timber when it was harvested, landowners were taxed for all standing timber. This created perverse incentives for landowners to cut their timber and subsequently the timber market was flooded with saw logs and pulpwood (Interview 79).

Fifteen interviewees (12\%) mentioned their state’s renewable portfolio standards (RPS). Nine (7\%) interviewees felt their state's RPS facilitated biomass utilization. Four Colorado interviewees reported that the RPS could aid in woody biomass utilization if the definition of "biomass" was expanded. Woody biomass is currently excluded as a renewable source of energy. Related to this, three interviewees mentioned similar issues concerning the Federal Energy Act of 2005 in which biomass from the forest is also excluded from being counted as a renewable fuel feedstock. 
The "Fuels for Schools" program is funded through the National Fire Plan of 2000, but run by local and state organizations such as Resource and Conservation Districts. Today, some operational funding comes from the Economic Action Program of the USFS. Many past projects were funded with a combination of federal, state, and private grants. Eight (6\%) interviewees described the "Fuels for Schools" program as a worthwhile program which increased woody biomass utilization. Vermont had a similar program for public buildings, but it was suspended due to lack of funds. It is important to note that only eight states were represented in this research and other states have their own "Fuels for Schools" program. In addition, two interviewees reported that projects were utilizing material from sawmills instead of directly from the forest. One interviewee noted that their local Fuels for Schools projects competed with mills for high quality sawdust. This is due to the design of the school's boiler which required a feedstock with very low moisture content. Interviewees also indicated that initial funding for projects is crucial to project success. Two expressed beliefs that projects have to eventually support themselves. One felt Fuels for Schools was successful because the community was supportive of "small, scalable projects" and the program used existing technology. Another interviewee believed that creating markets for woody biomass was critical to the success of the "Fuels for Schools" program, while one noted that the actual amount of material a school used for an entire year was a "small" amount that did not warrant contractors investing in special logging and chipping equipment. While the Fuels for Schools program promoted woody biomass utilization, other states have policies that focus on the removal of woody biomass utilization. 
For instance, the State of Minnesota has official biomass harvesting guidelines in place, which four interviewees believe to be a positive action. The biomass harvesting guidelines address ecological concerns. Furthermore, five interviewees from Colorado discussed the recently passed forest improvement legislation which gave counties the ability to create a special tax in order to fund forest improvement districts. While the legislation has been signed into law, no county has utilized it because "no one likes taxes” (Interview 22). Two interviewees believe this is a good idea though it has yet to be utilized.

\section{Potential Future Policy Considerations}

Eighteen interviewees (14\%) believed that air quality regulations will become increasingly important factors in woody biomass utilization. According to five interviewees (4\%), air quality regulations were already impeding woody biomass utilization either at the local level or by discouraging new, large scale thermal and/or electrical plants. For instance, at the individual level, homeowners in Colorado moved away from using wood to heat their homes due to concerns about air quality. Air pollution from home wood heating systems is a real and perceived problem. Homemade wood boilers emit considerable pollution, however, EPA-certified woodstoves can be used on "no burn days” (Interview 27). On a larger scale, one interviewee reported that coal-fired power plants in Colorado were not interested in co-firing with biomass since they would need to obtain new and costly EPA permits to do so. However, several interviewees explained that air quality standards could also facilitate woody biomass utilization when they preclude controlled burning due to smoke management issues. 
A possible future issue for policymakers centers of the regulation of carbon dioxide emissions. Fourteen (11\%) interviewees believed carbon credits and/or carbon mitigation strategies will be important for future land management strategies and/or woody biomass utilization.

Finally, according to twenty-five (20\%) interviewees, grants and outside funding opportunities are critical to implementing woody biomass removal and/or utilization projects. These interviewees mentioned nonspecific grants and outside funding in relation to land management projects. 


\section{Chapter 6. Discussion}

Woody biomass utilization is a seemingly straightforward process - material is removed from the woods and used for wood products, thermal production, or electricity production. In reality, users of woody biomass must navigate a complex web of physical, regulatory, and economic barriers. From removal of material to utilization, my research shows there is not one problem or one major barrier, but rather a conglomeration of seemingly unrelated rules, economic realities, and organizational barriers. Some users have been able to navigate these barriers and successfully utilize woody biomass. Recent legislation at both the state and federal level support users of woody biomass.

My research complements and affirms much of the professional literature available (Evans, 2008, GAO 2001; 2005; 2008;) while connecting scholarly literature centered on either fire mitigation and perception (Brunson et al., 2004, Dale 2006; 2007; Keiter, 2006; Mason et al., 2006; Stephens et al., 2005;) or wood-based bioenergy (Gan 2005 and 2007; Hughes, 2000; Lowell et al., 2008), through my findings in regard to stewardship contracting and state policies. The “connection” required to utilize material from hazardous fuel reductions has already been identified as the need for federal funding (Becker et al., 2009) and increased stakeholder collaboration (Nechodom et al., 2008). Localized reports of successfully connecting fire mitigation and bioenergy exist (Farnworth et al., 2002; Iverson et al., 2005), however, my research adds to this body of literature with a discussion about the role of stewardship contracting. While fire mitigation tends to focus on removal, bioenergy tends to focus on utilization, but in reality, removal and utilization are not so easily separated. Both spheres of research 
highlight the need for effective communication with stakeholders.

Furthermore, my research illustrates the importance of state policies in promoting woody biomass utilization. This is similar to research on the importance of regional state coalitions centered on climate change mitigation (Bryne et al., 2007).

This discussion section is divided into two sections. First specific federal policies are discussed, followed with a discussion about federal agencies organizational barriers. Next, the roles of state policies are discussed. Chapter Seven will address ideas for future studies, limitations to this study, and several policy recommendations.

\section{Federal Policies and Organizational Constraints}

Results from the interviews showed that federal policies, for the most part, facilitate woody biomass utilization, but organizational constraints hinder woody biomass utilization. This research showed that $64 \%$ of interviewees mentioned a specific federal policy by name. Many of these interviewees discussed more than one policy. Results show that $18 \%$ of interviewees perceived positive outcomes from The National Fire Plan and $12 \%$ of interviews viewed HFRA (and HFRA-created CWPPs) as promoters of woody biomass utilization. Interviewees believed these two policies promoted removal through an increase in available funding for projects and national attention to the "fire problem”. The role of NEPA was mixed, since many interviewees reported negative perceptions, but found ways to dealt with perceived NEPA barriers. For instance, out of the $25 \%$ of interviewees who mentioned NEPA by name, the majority of them felt NEPA was a barrier to biomass utilization due to time constraints caused by the complexities of 
documentation and potential litigation. However, interviewees mentioned several strategies to ensure compliance with NEPA that would have a high chance of withstanding a court challenge. This is termed "bullet-proofing" and illustrated the precautionary approach to land management decisions centered on NEPA compliance. My research strengthens claims made by Antypas and McLain (2002) about the need for a precautionary approach due to a broad definition of "major federal action” created through NEPA case law.

My research shows, stewardship contracting is a major tool to facilitate woody biomass utilization. Twenty-seven percent of interviewees reported on the perceived benefits of stewardship contracting not only to forests, but to their communities as well. Interviewees from nine out of the ten case studies reported stewardship contracting as a positive tool for woody biomass utilization. Stewardship contracting is not used on a large scale (GAO, 2008), but my research confirms that interest and attempts at stewardship contracting is increasing.

Stewardship contracting was originally formed as a cost saving measuring (Hausbeck, 2007), but has potential to aid in woody biomass utilization especially in areas which need hazardous fuel reduction treatments by offsetting treatment costs. My research confirms this. Additionally, Mitosis (2001) described stewardship contracting as one way to lessen a perceived community divide between local employment and environmental protection. Stewardship contracting projects can have multiple objectives and outcomes centered since projects are based on "best value” rather than lowest cost. Several interviewees reported on the "best value" objectives of stewardship contracting 
including local job creation and forest restoration.

Stewardship contracting has been met with resistance from some communities that are dependent on revenue sharing from timber sales to fund local schools. This is because counties, especially in areas which are predominately comprised of federal land, receive a percentage of revenue from federal timber sales. Stewardship contracting reduces or (in theory) removes the exchange of money and fosters a "goods for services" exchange, thereby reducing counties’ revenue share. For example, my research found that the BLM had the local county commissioner approve stewardship contracting projects, though they do not legally need his permission. The purpose of the county commissioner's signature was to create good will. This illustrates the importance of agency and community collaboration.

The relationship between land management agencies and communities influence policy success (Dale, 2006). My research confirmed this through interviewee discussion about the importance of community "buy-in”, illustrated in the previous example. Additionally, $11 \%$ of interviewees discussed strategies to reduce possible NEPA-related litigation. These strategies involved creating a form of community "buy-in” typically through adjusting projects to gain community acceptance. Domac (2007) reports that the success of bioenergy projects depend on the public's perception of the project. Similarly, my research shows interviewees believe public perceptions are also important for hazardous fuel reduction projects. That is why some land managers go through NEPA "bullet-proofing”, such as not harvesting large diameter trees. This finding confirms research by Laband (2006) in which the likelihood of litigation increases if a project 
includes sawlog or large diameter timber harvesting. Though a small component, two interviewees from the South Carolina case study reported no problems or negative perceptions towards NEPA compliance since the community was supportive of their actions. This ties into the importance of public perceptions and complements findings about regional differences in land management perceptions (Brunson et al, 2004). Though originally formed as a cost-saving measure, stewardship contracting plays a crucial role, though it’s "best value” clause of bringing community support to land management activities.

Fire literature stresses the importance of public participation and community support (Brunson et al., 2004; Field, 2005; Dale, 2006), and stewardship contracting mandates increased public participation in land planning objectives (Hausback, 2007). Stewardship contracting is a policy vehicle for the federal government to aid in removal and use of woody biomass. Stewardship contracting increases collaboration at the local level especially due to its emphasis on "best value" projects. The U.S. Forest Service is no longer a timber dominated, extraction-orientated agency (Bosworth and Hutch, 2007) and as different values influence decision-making, successful collaboration is imperative (Creighton 2003; Cheng 2006). This is because, though collaboration and public participation activities may take more initial time, in the long-term, collaboration fosters a cooperative sense of community which ultimately saves project managers time and money (Creighton, 2003). While policy choices are inherently political choices, technical and scientific information is necessary to aid in decision-making (Stephens and Ruth, 2005). Community support aids in the political aspect of decision-making through 
consensus building and avoiding time-consuming litigation. An explicit goal of stewardship contracting is to increase collaboration in local projects.

Users of stewardship contracts suffer from barriers such as complexity of documents and inability to adapt contracts to changing market conditions (Gorte, 2001). Interviewees discussed these exact barriers. In regard to woody biomass removal (not timber), the uneconomical value of the goods-for-services exchange limits stewardship contracting. Bioenergy development is believed to be one way to add value to the traditionally low-value or no-value material which needs to be removed from the forests (Becker et al., 2009). As my research shows, one method to add value to this material is with federal and/or state tax credits and subsidies. The state policy section will discuss tax issues.

Over half of all interviewees discussed organizational barriers (such as budget constraints, staff turnover, or misdirected targets), mostly in regards to the USFS. These barriers affected the availability of material for woody biomass utilization. A reliable and economically feasible supply is a major concern for users of woody biomass (GAO, 2005). Several interviewees discussed the use of performance measures to quantify completed work. Interviewees felt "acres treated" was not synonymous with "priority acres” and often quantity of acres treated was more important than quality of acres treated. Dale (2006) explains this discrepancy and describes the importance of performance measures like "acres treated" though the multiple administrative layers of agencies such as the USFS. The importance of achieving a certain number of acres treated often has the perverse result of ignoring treatment in areas that need it the most. 
Often more acres can be treated on easily accessible land. This does not always correspond to areas that pose the greatest risk. My findings support Dale (2006) and show how people on the ground conceptualize this issue as agencies treating "easy" acres as opposed to "priority" acres. These types of barriers illustrate the shift the USFS is going through as it moves away from its once prominent timber-extraction mindset (Bosworth and Hutch, 2007).

My research shows that overall, federal policies and federal agencies are just one component of woody biomass utilization. Federal policies and agencies operate closely with state and local communities and governments. My research shows the role of state policies in woody biomass utilization plays a critical role in the overall success of projects.

\section{States Policies and Programs}

Nearly $40 \%$ of interviewees believed state policies played an important role in facilitating woody biomass utilization. Often, state policies provided economic incentives to encourage the use of woody biomass utilization as seen in case studies in Oregon, New Mexico, and Vermont. These state policies are able to adjust to localized and regional needs sometimes producing the same outcome. For instance, regional dependency on costly heating oil in Vermont promoted heating public buildings with wood. In Montana, fossil fuel costs were also an issue, but funding to use wood to heat public buildings was initially derived from the National Fire Plan. Local and state organizations continued the program with funding from the economic action programs of the USFS. 
Mitigating community risks to wildfires is an easy goal for the public to support, but a difficult goal to implement (Brunson et al, 2004). A federal strategy has been to create markets to give woody biomass value (Nechodom et al, 2007). My research illustrates an unintended consequence of this market creation through the Fuels for Schools program. This discussion is included in the state policy section since local and state organizations are responsible for the on-the-ground implementation of this program.

Fuels for Schools is a program where a school (or public) building switched to wood heating. Initial conversion costs are typically paid with federal funding. States and local organizations typically administer the program. A Fuels for Schools program was only discussed in the Montana case study. In this case study several interviewees reported that only high quality sawmill residues could be used in a school's boiler. Material removed directly from the forest (such as from a hazardous fuel treatment) could not be used as fuel for the boiler. While interviewees were not clear about the overall goal of the Fuels for Schools project, it did not contribute to hazardous fuel reductions. This illustrates the complexities and planning of government funded projects. This example confirmed findings by Becker (2009) about the complexities of market creation for woody biomass utilization. Specifically, that one policy or program is not enough to create a market for woody biomass utilization, but rather parallel initiatives need to occur so projects can complement and promote each other. For instance, in the example from my research, a small wood products firm would complement the situation. The firm could utilize woody biomass from hazardous fuel reduction projects and their sawdust residues could be utilized by the local school for heat. Becker (2009) refers to this as "clustering" 
projects.

My research highlights different state policies and the importance of these policy choices to woody biomass utilization. Iverson (2005) and Farnsworth (2002) illustrate the importance of collaboration with a community to implement a successful bioenergy project.

Though focused on fuel reductions and not a bioenergy project, my research reported on local efforts in which private property owners in New Mexico faced an increase in property taxes if hazardous fuel loads on their property were not reduced. This ordinance became law due to community support. According to the authors, ecological and technological barriers are easier to overcome than social, political, and financial issues. State policies that promote woody biomass utilization most often aid in the economic feasibility of woody biomass projects. Furthermore, 7\% of interviewees believed renewable portfolio standards at the state level promote woody biomass. However, four interviewees reported that their state RPS had a narrow definition of biomass and material collected from the forest was not permissible. Renewable portfolio standards represent a social change valuing renewable energy. This further illustrates the importance of addressing social and political issues to encourage woody biomass utilization.

Furthermore, local issues of importance include air quality issues such as smoke concerns due to prescribed burning (Dale, 2007). I found that real and perceived air quality problems exist. For instance, in Colorado interviewees report that a negative perception exists about heating homes with wood. Additionally, a few interviewees 
mentioned the difficulties in obtaining emissions permits from the EPA for biomass cofiring plants. 


\section{Chapter 7. Policy Recommendations and Conclusion}

\section{Policy Recommendations}

My findings led to several policy recommendations. First, woody biomass utilization is a growing economic sector and will be increasingly important for two reasons. WBU can be used as a tool to offset costs associated with hazardous fuel reduction treatments and the removed material can be used as a feedstock for renewable energy activities. Therefore, policies should be crafted which recognize this dual role. Additionally, since sustainably harvested wood is considered carbon neutral (Malmsheimer et al., 2008), if limits on carbon dioxide were to be legislated in the United States, this could create a third use for woody biomass. Therefore policy makers should be aware of this potential use and keep up to date on new policies regarding carbon dioxide emissions, trading, and credits, all of which could impact woody biomass utilization. Furthermore, it may be beneficial for federal policymakers to create regional specific policies for woody biomass utilization.

A strong recommendation for future policy makers based on this research is to renew stewardship contracting legislation, which is set to expire at the end of fiscal year 2013. This research shows that stewardship contracting, while not without its problems, is a tool that can facilitate woody biomass utilization and is one of the most helpful USFS and BLM policies. Since, interviewees reported difficulty navigating the paperwork associated with a stewardship contract, perhaps a training handbook or guide could be developed. Furthermore, perhaps the USFS could develop workshops and seminars to 
help government employees, loggers, and community members become familiar and comfortable with stewardship contracting.

\section{Limitations}

My research has limitations. First of all, environmental groups could have been better represented. Additionally, local political officials might have been able to provide useful insight. Interviewees were mostly public land management agency employees, many of them worked for the USFS. This could explain why organizational barriers, specifically about the USFS, were frequently volunteered throughout the interviews. Additionally, it would have been preferable to have the same individuals perform every interview in order to ensure consistency and accuracy with asking every question. While interviewees were allowed significant latitude to discuss issues they felt important, different interviewers were able to encourage interviewees to elaborate on answers by asking targeted follow-up questions. All interviewers followed the standard interview guide, yet some interviewers probed certain subjects more intensely due to their knowledge and ability on forest management issues. Six individuals conducted these interviews, usually in groups of two, due to the scope and size of the interviewee pool.

\section{Avenues for Future Research}

Future research should pursue several avenues. First of all, the larger project which my research was derived from was meant to capture a broad view of "lessons learned” about woody biomass utilization activities. Ten case studies were used spanning eight states. Three of the cases were east of the Mississippi River and only one was in the 
southeastern United States. Since the Joint Fire Sciences Program funded the larger project, it had an emphasis on woody biomass utilization as a wildfire mitigation tool. Future researchers may want to examine woody biomass utilization apart from its potential wildfire mitigation use. Perhaps an avenue of future research would be to examine areas that are utilizing biomass for renewable energy purposes. Future researchers may want to examine the role of woody biomass utilization in more detail in the southeastern part of the country for bioenergy.

Additionally, future avenues of research could address the issue of social acceptability of woody biomass utilization according to forest disturbance regime. Forest disturbance regimes have geographic variability with some areas dominated by fire, some by wind damage, and areas increasingly affected by the Mountain Pine Beetle epidemic. It would be beneficial to study how the difference disturbance regimes impact woody biomass utilization activities. Related to this, woody biomass utilization could be studied on a more regional and landscape level instead of confined to artificial boundaries such as states, National Forests, and public land boundaries.

Thirty-seven percent of interviewees believe specific state policies and/or programs promote woody biomass utilization. For instance, without local and state organizations in Montana supporting the "Fuels for Schools" program it would not have been able to continue. Furthermore, tax credits provided by the State of Oregon proved to be essential to woody biomass utilization. Therefore, an interesting future project would be to focus on the role of states in facilitating woody biomass utilization. Specifically, it would be useful to separate states into regional coalitions based on forestland and assess 
woody biomass utilization at a regional scale. In this way, studies could be better targeted to focus on specific activities in a region and then compared across regions. This might provide a clearer picture of nationwide woody biomass activities. Furthermore, states are already forming regional coalitions in regards to carbon markets and voluntary limits on carbon emissions (Bryne et al., 2007; Janowiak, 2008). Using these regional boundaries to assess woody biomass utilization could provide valuable information and may illustrate linkages between state climate change policies and renewable energy policies in regard to woody biomass utilization.

\section{Conclusion}

In conclusion, I found that policies are just one part of the complex public land management process in the United States. There is no one main policy or program that impedes or facilitates woody biomass utilization. However, added together federal and state policies impact woody biomass utilization by promoting the removal and utilization of biomass. Federal policies such as the National Fire Plan and HFRA provided funding to reduce wildfire risk to communities. This often results in projects with removed material. Stewardship contracting attempts to create value for hazardous fuel reductions by exchanging material for service work. The material has to have value in order for this to work. State tax policies often create value for removed material through economic incentives. Additionally, programs like Fuels for Schools attempt to create a market for removed material. Barriers arise due to agency organizational constraints in policy implementation. I discussed the negative impacts of staff reductions, budget problems, and misdirected performance targets, which were reported by over half of 
interviewees. State renewable portfolio standards may play a crucial role in promoting future woody biomass utilization, but only if biomass removed from forests is permissible. Overall, woody biomass utilization has the potential to assist in wildfire mitigation and renewable energy goals, however, economic barriers still exist. 


\section{Bibliography}

Aulisi, Andrew, A. Sauer, and F. Wellington. (2008). Trees in the Greenhouse: Why Climate Change is transforming the Forest Products Business. World Resources Institute. Last Accessed Oct 20, 2008 from http://www.wri.org/publication/treesin-the-greenhouse

Antypas, A. and R. McLain. (2002). Federal Nontimber Forest Products Policy and Management. In E. Jones, R. McLain, and J. Weigand (Eds.), Nontimber Forest Products in the United States. Lawrence, KS: University Press of Kansas. 347374.

Becker, D., M. Nechodom, A. Barnett, T. Mason, E. Lowell, J. Shelly, and D. Graham. (2009). Assessing the Role of Federal Community Assistance Programs to Develop Biomass Utilization Capacity in the Western United States. Forest Policy and Economics, 11(2): 141-148.

Bosworth, D. and H. Brown, (2007). After the Timber Wars: Collaborative Community Based Stewardship. Journal of Forestry, 105(5): 271-273.

Brunson, M. and B. Shindler. (2004). Geographic Variation in Social Acceptability of Wildland Fuels Management in the Western United States. Society and Natural Resources. 17(8): 661-678

Bryne, J. and K. Hughes. (2007). American Policy Conflict in the Greenhouse: Divergent trends in Federal, Regional, State, and Local Green Energy and Climate Change Policy. Energy Policy. 55(9): 4555- 4573. 
Burns, M. and A. Cheng. (2007). Framing the Need for Active Management for Wildfire Mitigation and Forest Restoration. Society and Natural Resources 20(3): 245-259

Cheng, A. (2006). Build It and They Will Come? Mandating Collaboration in Public Lands Planning and Management. Natural Resources Journal, 46: 841-858.

Creighton, J. (2003). The Public Participation Handbook. San Francisco: Jossey-Bass.

Dale, L. (2006). Wildfire Policy and Fire Use on Public Lands in the United States. Society and Natural Resources. 19(3): 275-284

Dale, L., A. Gerlak. (2007). It's All in the Numbers: Acreage Tallies and Environmental Program Evaluation. Environmental Management, 39: 246-260.

Domac, J., K. Richards, and S. Risovic. (2005). Socio-economic drivers in implementing bioenergy projects. Biomass and Bioenergy. 28: 97-106.

Ekstrom, H. (2008). Wood Resources International. Worldwide Trade of Wood Pellets Reached a Record Three Million Tons in 2007. Retrieved on March 23, 2009 from: www.newsdesk.se/view/pressrelease/worldwide-trade-of-wood-pelletsreached-a-record-three-million-tons-in-2007-220698

Evans, A. (2008). Synthesis of Knowledge from Woody Biomass Removal Case Studies. Forest Guild and US Forest Service Technical Report. Last accessed on March 23, 2009 from: http://www.forestguild.org/publications/research/2008/Biomass_Case_Studies_Re port.pdf

Evans, A. and G. McKinley. (2007). An Evaluation of Fuel Reduction Projects and the Healthy Forests Initiative. Forest Guild Research Paper. Last accessed on March 
23, 2009 from:

http://www.forestguild.org/publications/research/2007/Evaluating_HFI.pdf

Farnsworth, A., P. Summerfelt, D. Neary, and T. Smith. (2003). Flagstaff's wildfire fuels treatments: prescriptions for community involvement and a source of bioenergy. Biomass and Bioenergy 24: 269-276.

Field, D. and D. Jensen. (2005). Humans, Fire and Forests: Expanding the Domain of Wildfire Research. Society and Natural Resources. 18(4): 355- 362.

Gan, J. and C.T. Smith. 2005. A comparative analysis of woody biomass and coal for electricity generation under various $\mathrm{CO} 2$ emission reductions and taxes. Biomass and Bioenergy 30: 296 - 303.

Gan, J. and C.T. Smith. 2007. Co-benefits of utilizing logging residues for bioenergy production: The case for East Texas, USA. Biomass and Bioenergy 31:623-630

Gorte, R. (2001). Stewardship Contracting for the National Forests. CRS Report RS20985. Washington, DC: Penny Hill Press.

Hausbeck, K. (2007). The Little Engine that Could: The Success of the Stewardship Contracting Authority. William and Mary Environmental Law \& Policy Review, 32: 33-55.

Hughes, E. (2000). Biomass Cofiring: Economics, Policy, and Opportunities. Biomass and Bioenergy 19: 457-465.

Iverson, K. and R. Van Demark. (2005). Integrating fuel reduction management with local bioenergy operations and businesses - A community responsibility. Biomass and Bioenergy 30: 304 - 307. 
Janowiak, Maria. Personal communication. Guest Lecture for FW3110 at Michigan Technological University, Houghton, Michigan. March 2008.

Jones, E. and K. Lynch. (2002). The Relevance of Sociocultural Variable to Nontimber Forest Product Research, Policy, and Management. In E. Jones R. McLain, and J. Weigand (Eds.), Nontimber Forest Products in the United States. Lawrence, KS: University Press of Kansas. 26-53

Kneeland D. and A. Perlis. (2008). Forests and Energy: Key Issues. Food and Agricultural Organization of the United Nations.

Keiter, R. (2006). The Law of Fire: Reshaping Public Land Policy in an Era of Ecology and Litigation. Environmental Law, 36(2): 301-384.

Laband, D., A. Gonzalez-Caban, and A. Hussain. (2006). Factors that Influence Administrative Appeals of Proposed USDA Forest Service Fuels Reduction Actions. Forest Science, 52(5), 477-488.

Lowell, E., D. Becker, R. Rummer, D. Larson. (2008). An Integrated Approach to Evaluating the Economic Costs of Wildfire Hazard Reduction Through Wood Utilization Opportunities in the Southwestern United States . Forest Science, 54(3): 273-283.

LeVan-Green, S. and J. Livingston. (2001). Exploring the Uses For Small-Diameter Trees. Forests Product Journal , 51(9), 10-21.

Malmsheimer, R., P. Heffernan, S. Brink, D. Crandall, F. Deneke, C. Galik E. Gee, J. Helms, N. Mcclure, M. Mortimer, S. Ruddell, M. Smith, and J. Stewart. (2008). Forest Management Solutions for Mitigating Climate Change in the United States. 
Journal of Forestry. 106(3) 115-171.

Martin, W., C. Raish, B. Kent Eds. (2008). Wildfire Risk: Human Perceptions and Management Implications. Resources for the Futures Press, Washington DC.

Mason, C., B. Lippke, K. Zobrist, and T. Bloxton, K. Ceder, J. Comnick, J. McCarter, H. Rogers. (2006). Investments in Fuel Removals to Avoid Forest Fires Result in Substantial Benefits. Journal of Forestry, 104(1): 27-31.

McKee, M., R. Berrens, M. Jones, R. Helton, J. Talberth. (2004) Using Experimental Economics to Examine Wildfire Insurance and Averting Decisions in the Wildland-Urban Interface. Society \& Natural Resources 17(6): 491-507.

Mitosis, M., and P. Ringgold. (2001). Testing Stewardship Concepts on Federal Land. In G. Gray M. Enzer, \& J. Kusel (Eds.), Understanding Community-Based Forest Ecosystem Management. The Hawthorth Press. 305 - 320.

Moseley, C. and N. Toth. (2004). Fire Hazard Reduction and Economic Opportunity: How are the Benefits of the National Fire Plan Distributed?” Society \& Natural Resources 17(8): 701-716.

Murphy, J., P.Smith, and J. Wiedenbeck. (2007) Wood Residue Utilization in Pennsylvania 1988 vs 2003. Forest Products Journal. 57(4) 101:106

Nechodom, M., D. Becker, D., and R. Haynes. (2008). Evolving Interdependencies of Community and Forest Health. In E. Donoghue \& V. Sturtevant (Eds.), Forest Community Connections: Implications for Research, Management and Governance . Washington, DC: RFF Press. 
Parikka, M. (2004). Global biomass fuel resources. Biomass and Bioenergy 27: 613 620.

Peska-Blanchard M., P. Dolzan, A. Grassi, J. Heinimo, M. Junginger, T. Ranta, and A. Walter. (2007). Global wood pellets markets and industry: policy drivers, market status, and raw material potential. IEA Bioenergy Task 40. Last Accessed on March 24, 2009 from:

http://www.bioenergytrade.org/downloads/ieatask40pelletandrawmaterialstudyno v2007final.pdf

Perlack, R., L. Wright, A. Turhollow, R. Graham, B. Stokes, and D. Erbach. (2005). Biomass as a feedstock for bio-energy and bio-products industry: the technical feasibility of a billion ton annual supply. US Department of Energy. DOE/GO 102995-2135. April 2005.

Skogen, K. (2003). Adapting Adaptive Management to a Cultural Understanding of Land Use Conflicts. Society and Natural Resources, 16(5): 435-450.

Stephens, S. and L. Ruth. (2005). Federal Forest-Fire Policy in the United States. Ecological Applications 15(2): 532 - 542.

United States Department of Agriculture, United States Department of Interior, and United States Department of Energy. Memorandum of Understanding on Policy Principles for Woody Biomass Utilization for Restoration and Fuel Treatments on Forests, Woodlands, and Rangelands. 2003 Last Accessed Oct 21, 2008 from http://www.fs.fed.us/woodybiomass/documents/BiomassMOU_060303_final_we b.pdf

United States Department of Agriculture, Forest Service Woody Biomass Utilization Strategy. FS-899. February 2008. Last Accessed on April 26, 2009 from 
http://www.fs.fed.us/woodybiomass/strategy/documents/FS_WoodyBiomassStrat egy.pdf

United States Department of Agriculture and United States Department of the Interior. Healthy Forests and Rangelands. Site last Accessed on Oct. 29, 2008 from http://www.forestsandrangelands.gov/index.shtml

United States Department of Agriculture, Forest Service. Woody Biomass Utilization. Site last Accessed on March 24, 2009 from http://www.fs.fed.us/woodybiomass/whatis.shtml

United States Department of Energy. Energy Efficiency and Renewable Energy. States with Renewable Portfolio Standards. Last Accessed Oct 29, 2008 from http://apps1.eere.energy.gov/states/maps/renewable_portfolio_states.cfm

United States Energy Information Administration. Electricity Infocard. Accessed at: http://www.eia.doe.gov/bookshelf/brochures/electricityinfocard/elecinfocard2006/ elecinfocard.html

United States General Accounting Office . (2001). The National Fire Plan: Federal Agencies are not Organized to Effectively and Efficiently Implement the Plan . GAO-01-1022T July 31. Washington D.C.

United States General Accounting Office. (2005) Woody Biomass Users' Experiences Offer Insights for Government Efforts Aimed at Promoting Its Use. March. GAO06-336 Washington D.C.

United States General Accounting Office. (2008) Use of Stewardship Contracting is Increasing, but Agencies Could Benefit from Better Data and Contracting Strategies. GAO-09-23 November. Washington D.C. 
Warren, W. (2007). What is a Healthy Forest? Definitions, Rationales, and the Lifeworld. Society and Natural Resources, 20(2): 99-117.

Walsh, M.E. (2007). Agricultural Impacts of Biofuels Production. Journal of Agricultural and Applied Economics 39(2): 365-372.

Wynsma, B., R. Aubuchon, D. Len, M. Daugherty, and E. Gee. Woody Biomass Utilization Desk Guide. United States Department of Agriculture, Forest Service 2007. Last accessed on Oct 20, 2008 from www.forestsandrangelands.gov/Woody_Biomass/documents/biomass_deskguide. pdf 
Appendix A. Individual Case Study Overview 
Northern California - Ten interviews were conducted describing biomass utilization efforts in and around the Shasta-Trinity National Forest in Northern California. Six interviews were conducted with governmental employees; four from the USFS and two from state entities. One member of a NGO was interviewed and three members of industry were interviewed. These interviews revealed a complex story centered on the different roles of this 2.1 million acre forest in tourism, recreation, and the forest product industry. Parts of the Shasta-Trinity National Forest face heavy litigation and contain difficult terrain in which to remove biomass. In this area, biomass removal is critical due to the risk of catastrophic wild fire. Bureau of Land Management (BLM) personnel in the area seems to have a less difficult time with timber and biomass harvesting. BLM personned used tactics which encouraged community collaboration to accomplish projects. For instance, in one case, the BLM forester placed ribbons on trees and negotiated which trees would be harvested with community members. The communication and people skills of the BLM forester's communication and people skills highlight the importance of "bridge people" in woody biomass utilization projects.

In this area, several industries currently utilize biomass. Several sawmills are use woody biomass for on-site heat and electricity production. In Hayfork, California, the presence of Jefferson Forest Products, a specialty wood product firm, influences the health of this area's microeconomic climate. Issues with availability of biomass supply are critical to address since there is an available, although limited, infrastructure to utilize biomass. This case study illuminated the importance of linkages and partnerships 
between federal, state, NGO, and private industry in biomass utilization projects.

Front Range of Colorado - The Front Range of Colorado refers to the part of the Rocky Mountains where a westbound traveler first encounters the mountains in Colorado. This area in north-central Colorado contains a considerable amount of the state population and major cities. A series of fourteen interviews were conducted in the Front Range region; eleven with government employees, one member of a NGO, and two people from forest products industry. The landscape in this area has been heavily affected by the Mountain Pine Beetle (MPB) with an estimated 1.5 million acres of lodgepole pine killed. These dead trees are increasing the risk of catastrophic wildfires in the region especially in the wild-land urban interface (WUI). The Araphahoe-Roosevelt National Forest in the Front Range has over 30,000 homes within the forest boundaries and the regional population is over half a million people. The steep terrain presents difficulties for woody biomass removal. While the concern about wildfire is great, the lack of a well-formed forest product industry in the Front Range results in low demand for woody biomass. Small industries centered on wood products are hampered by the inconsistent supply availability from the extensive federal land in the areas and the high costs associated with transportation. Furthermore, fire wood or possible wood-based bio-energy production created concern about air quality in the area. While governmental and non-governmental entities are trying to create a "culture of utilization", significant work remains to combat challenges not only from landscape issues, but challenges posed by the parcelization and privatization of land in the area. 
South-central New Mexico - This case focused on the reservation land of the Mescalero Tribe and the adjacent Lincoln National Forest. This case study is comprised of eleven interviews with six governmental employees, four industry representatives, and one tribal employee.

Very strong local and tribal governments influence this isolated area in New Mexico. Community members are concerned about the wildfire risk in the WUI. USFS has been criticized for performing fuel reductions on what is consider "easy" land. This is relatively flat and easy to access land. Concern exists about the fuel loads on the abundant steep slopes of the area. Some community members view biomass utilization as an attempt to increase logging.

This case study highlights the crucial role of local governments and tribes for woody biomass utilization. For instance, the town of Ruidoso devised an innovated approach to reduce fuel loads on private land. The town of Ruidoso passed a city ordinance that landowners cannot have excessive woody biomass on their property or they will face an increase in their property taxes. The landowners place woody biomass on the side of the road in front of their property and a local business collects and uses the material for landscape mulch. The community supports this activity.

A few wood product companies are represented in this story. They struggle to secure wood from federal lands and struggle with transportation costs. A more reliable supply of wood is available from tribal lands. 
Coastal South Carolina - This study focused on the Francis Marion National Forest and the Sumter National Forest. Twelve interviews were conducted; eight interviews from governmental employees and four interviews from members of the forest industry community. Significant blow-down occurred in this area in 1989 due to Hurricane Hugo. The re-growth from that event contains a significant amount of small diameter trees and woody shrubs. Land managers are concerned about reducing these fuel loads to mitigate potential wildfires and to provide suitable habitat for the red cockaded woodpecker - a federally endangered species. In this area of the country, controlled burns work very well and are often cheaper than removing woody biomass. Some areas have smoke concerns especially if highways are nearby. However, large paper mills located near the Francis Marion National Forest have created a considerable demand for wood chips. The mills use the wood chips for electricity and heat production. Concern surrounds the availability of low-cost wood chips for these mills to purchase, especially if increased competition arises due to other alternatives for woody biomass.

Southwestern Oregon - This case study focused on woody biomass utilization activities on the Rogue River-Siskiyou National Forest and BLM lands in southwestern Oregon. Eighteen interviews were collected consisting of nine government employees and eight industry representatives. Woody biomass utilization in Oregon is closely tied to the forest products industry and the emerging bio-energy business. One of the largest users of woody biomass is the Biomass One power plant which currently faces supply issues. Woody biomass utilization is affected through a series of state tax credits at the 
manufacturing, transportation, and production steps in utilization. Stewardship contracting is an important tool for industry to access resources on federal lands, but this tool has created limited success. The BLM seems able to create successful stewardship contracts, while the USFS struggled with litigation. Poor road conditions on federal land and the steep terrain of the area hamper woody biomass utilization. Non-energy related industries, such as producers of animal bedding are important users of woody biomass.

Central Oregon - This case study centered on the Confederate Tribes of Warm Springs reservation, Deschutes National Forest, and BLM lands encompassing over 2.6 million acres of land. This case study is comprised of thirteen interviews, five from government employees, three from NGOs, and five interviews from industry representatives. This case study had three major interacting parts revolving around a purposed co-generation plant, a non-profit group dedicated to reducing hazardous fuel fire loads, and the ability of the Deschutes National Forest staff to foster collaborative projects to reduce hazardous fuel loads. The co-generation plant on the Confederate Tribes of Warm Springs' land would be a twenty mega-watt plant utilizing biomass as a feedstock. Two other power plants are purposed for the area.

Many smaller industries, such as animal bedding producers, do not rely on or use biomass from federal lands due to the unreliable and inconsistent supply. Several examples of successful partnerships between NGOs and industry are in this case study along with the success of state tax credits in promoting woody biomass utilization. 
Southwest Colorado - This case focused on the San Juan public lands consisting of 2.5 million acres of co-managed USFS and BLM land in the southwest corner of Colorado. This case study involved twenty interviews from eighteen governmental employees and two tribal foresters. In 2002, a major fire swept through this area. As a result, partnerships centered on biomass utilization were formed. Perhaps the greatest challenge for this area is the land's remoteness. The nearest sawmill required over one hundred miles of travel. The Colorado State Forest Service promoted woody biomass utilization through local and regional markets creation. An example of this is a proposal for wood pellet plants on tribal lands in the area and proposed bio-energy plants in Pagosa Springs. Markets for firewood represent a considerable demand for woody biomass material. In addition, some woody biomass is mulched and left in the forest in order to reduce hazardous forest fuel loads. This created community concern about forest ecology impacts.

Bitterroot Valley Montana - This fifteen-interview case study focused on the Bitterroot National Forest in west-central Montana. Eleven governmental employees were interviewed along with two members of the NGO community and two industry employees. Wildfires, drought, and MPB effects are major concerns for community members in this area. At the state level, partnerships such as the Smallwood Utilization Network, promote woody biomass utilization. The State of Montana actively encourages the Fuels for Schools program in which schools and other public buildings receive woodpowered heating systems. These boiler systems can use wood chips from woody biomass 
utilization projects. Many states have Fuels for Schools type project.

Larger scale users of woody biomass included wood products industries and log home manufacturers. This case study highlighted the possibilities of woody biomass utilization for a wide variety of goods and services. This case is interesting since, Historically, wood harvesting in this area focused on large-diameter sawlogs. Integrating small-diameter woody biomass into the existing forest product cluster illustrated challenges and insights into the power of partnerships.

Northeast Minnesota - The case study focused on biomass utilization activities within the "arrowhead" region of northeast Minnesota. Thirteen interviews were conducted representing eight governmental employees, four industry employees, and one member of an NGO. A considerable amount of interest in Minnesota revolved around the idea of wood for large scale heating and electricity usage. Minnesota has a new Renewable Portfolio Standard requiring 25\% of energy in the state to come from renewable sources. Biomass is expected to play a large role in meeting this objective. In the Superior National Forest, numerous biomass activities are underway or proposed. This "rush" to build pellet plants and bio-refineries creates concern about increased demand for wood chips and woody biomass. There is also concern that wood which could be used for pulp and paper will be directed to bio-energy usage. However, due to transportation costs, sawmill residues are currently the main feedstock for wood-based bio-energy production. Concern also exists about woody biomass removal impacts on soil productivity. 
Green Mountain, Vermont - This case study is drawn from seven interviews consisting of four government employees and three industry employees. This case study focuses on the Green Mountain National Forest in Vermont. In this area of the country, woody biomass utilization is fully integrated into the wood products industry, so much so, that wood chips for energy are worth more than wood chips for pulp and paper. Wood products play a diverse role in this region from high-end furniture, to wood chips for electricity and heat, to traditional firewood. The competition for raw material is creating some tension, but the integration of woody biomass utilization into the forest products supply chain appears an easier transition in this case study than in other case studies.

Woody biomass utilization is expanding in this region. Examples of projects include a fifty mega-watt power plant in the city of Burlington, wood boilers in over $25 \%$ of the public schools, and the unique program at Middlebury College, which built their own small wood-powered heating plant to replace the use of heating oil. Middlebury College currently grows short rotation woody crops in order to supply their own feedstock. The "community-scale” project is a recurring theme in the Green Mountain Region. 
Appendix B. Case Study Interview Questions 


\section{Interview Questions}

1. Please introduce yourself. How long have you worked in the area and in what capacity?

2. What is your role in biomass removal and utilization? How is it related to area efforts?

3. What activities have been taking place to remove and use biomass in your area?

4. How is biomass utilization helping you achieve forest management goals?

5a. Who do you consider strategic partners in these efforts? Who's not involved that should be?

5b. What has the federal, state or local government's role been?

5c. What about private enterprise?

5d. What about non-governmental organizations?

5e. How has involvement from the local partners and the community affected efforts?

6. Describe the collective strategy for biomass utilization in the area. What are the desired outcomes?

7a. What have been the key factors/opportunities leading to increased biomass utilization in the area?

7b. What efforts have worked and how have they affected progress?

7c. What has been done to help develop or capitalize on these opportunities?

8a. What have been the key challenges/barriers to biomass utilization?

8b. What efforts have not worked and how have they affected progress?

8c. What has been done to overcome these challenges?

9. What are you doing to capitalize on opportunities? What challenges must you still overcome? What efforts are needed in the long-run? 
10. Describe the scale of planning or utilization that works best for your situation.

11. What are your potential biomass utilization targets?

12. What are the physical and/or ecological constraints/opportunities for biomass utilization?

13. To what degree are utilization businesses economically viable?

14. What pieces to the utilization puzzle are missing?

15a. What contributes to the agency's ability to encourage utilization? What could the federal agencies do better to facilitate utilization?

15b. What kinds of agency factors contribute to their ability to partner with communities?

15c. Which state and/or federal policies/credits/practices best facilitate biomass utilization? Why?

15d. How well have the different authorities/mechanisms used, worked?

16a. Has/will biomass utilization created new economic development opportunities?

How?

16b. What has been the role of local communities and partner organizations in contributing to development of biomass utilization enterprises?

16c. What community factors are most lacking?

17. Have there been any surprises or unanticipated effects of biomass utilization?

18. Has your thinking changed about biomass utilization strategies over the past several years? In what ways? What has contributed to your change in your thinking?

19. What are your predictions on the long-term possibilities of your biomass utilization 
efforts?

20. What lessons would you would pass on to other communities and forests? What is stopping you from reaching your goals?

21. Anything else you would like to add? Something we didn't ask that you thought we should?

22. Are there other people in this forest or in the community we should speak with? 